NUBIA REGINA MOREIRA FRANÇA

\title{
ESTUDO TOPOGRÁFICO DA ANALGESIA INDUZIDA POR ESTIMULAÇÃO ELÉTRICA TRANSDURAL DO CÓRTEX MOTOR DE RATOS: SOMATOTOPIA DE RESPOSTA COMPORTAMENTAL E PERFIL DE ATIVAÇÃO NEURONAL
}

Dissertação apresentada ao Programa de PósGraduação em Ciências Morfofuncionais do Instituto de Ciências Biomédicas da Universidade de São Paulo, para obtenção do Título de Mestre em Ciências.

São Paulo 


\section{ESTUDO TOPOGRÁFICO DA ANALGESIA INDUZIDA POR ESTIMULAÇÃO ELÉTRICA TRANSDURAL DO CÓRTEX MOTOR DE RATOS: SOMATOTOPIA DE RESPOSTA COMPORTAMENTAL E PERFIL DE ATIVAÇÃO NEURONAL}

Dissertação apresentada ao Programa de PósGraduação em Ciências Morfofuncionais do Instituto de Ciências Biomédicas da Universidade de São Paulo, para obtenção do Título de Mestre em Ciências.

Área de Concentração: Ciências Morfofuncionais.

Orientadora: Profa. Dra. Camila Squarzoni Dale.

Versão original

São Paulo 
DADOS DE CATALOGAÇÃO NA PUBLICAÇÃO (CIP)

Serviço de Biblioteca e Informação Biomédica do

Instituto de Ciências Biomédicas da Universidade de São Paulo

reprodução não autorizada pelo autor

\section{França, Nubia Regina Moreira.}

Estudo topográfico da analgesia induzida por estimulação elétrica transdural do córtex motor de ratos: somatotopia de resposta comportamental e perfil de ativação neuronal / Nubia Regina Moreira França. -- São Paulo, 2012.

Orientador: Profa. Dra. Camila Squarzoni Dale.

Dissertação (Mestrado) - Universidade de São Paulo. Instituto de Ciências Biomédicas. Departamento de Anatomia. Área de concentração: Ciências Morfofuncionais. Linha de pesquisa: Neuroplasticidade associada a síndromes dolorosas complexas.

Versão do título para o inglês: Topographical evaluation of the analgesic effect induced by transdural electrical stimulation of the motor cortex of rats: somatotopy of behavioral response and profile of neuronal activation.

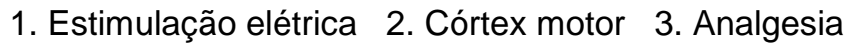
I. Dale, Profa. Dra. Camila Squarzoni II. Universidade de São Paulo. Instituto de Ciências Biomédicas. Programa de Pós-Graduação em Ciências Morfofuncionais III. Título. 
Candidato(a): Nubia Regina Moreira França.

Título da Estudo topográfico da analgesia induzida por estimulação elétrica transdural do córtex motor de ratos: somatotopia de resposta comportamental e perfil de ativação neuronal.

Orientador(a): Profa. Dra. Camila Squarzoni Dale.

A Comissão Julgadora dos trabalhos de Defesa da Dissertação de Mestrado, em sessão pública realizada a

\section{( ) Aprovado(a)} ................................, considerou

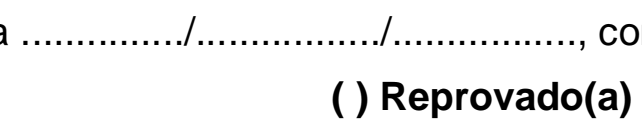

Examinador(a): Assinatura:

Nome:

Instituição:

Examinador(a): Assinatura:

Nome:

Instituição:

Presidente: Assinatura:

Nome:

Instituição: 
UNIVERSIDADE DE SÃO PAULO

INSTITUTO DE CIÊNCIAS BIOMÉDICAS

Cidade Universitária "Armando de Salles Oliveira"

Paulo, SP - Brasil

Telefone :(55) (011) 3091.7733 - e-mail: cep/ $a$ icb.usp.br

\section{Certificado}

Certificamos que o protocolo registrado sob $n^{\circ} \mathbf{1 2 2}$ nas fls. 93 do livro 02 para uso de animais em experimentação, sob a responsabilidade do $\operatorname{Prof}(a) \operatorname{Dr}(a)$

Camila Squarzoni Dale, Coordenador(a) da Linha de pesquisa Estudo topográfico da analgesia induzida por estimulação elétrica transdural do córtex motor de ratos: somatotopia de resposta comportamental e ativação neuronal do qual participam o(s) alunos Nubia Regina Moreira França, está de acordo com os Princípios Éticos de Experimentação Animal adotado pela Sociedade Brasileira de Ciência de Animais de Laboratório (SBCAL) e foi aprovado pela COMISSÃO DE ÉTICA NO USO DE ANIMAIS (CEUA) em 06.12.2010, com validade de 3 anos.

São Paulo, 08 de dezembro de 2010.
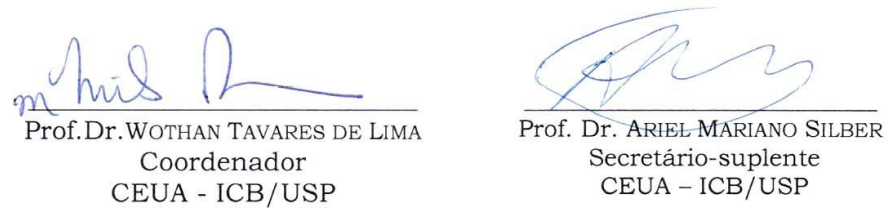
"Aos que direta e indiretamente contribuem ou contribuíram com o meu crescimento como ser humano" 


\section{AGRADECIMENTOS}

Deus, muito obrigada por tudo o que tens feito na minha vida.

Ao meu pai biológico que infelizmente não pode me acompanhar e ver muitas das vitórias que eu já tenho conquistado em minha vida.

À minha "mamadi" querida que sempre me ensina como ser uma pessoa melhor, sempre se preocupa e cuida de mim.

Aos meus irmãos Noely e Neilson que embora não compreendam os diversos caminhos que eu tenho trilhado sempre me acompanham e me ajudaram nessa etapa até pesquisando e digitando para mim.

À minha tia Rosângela que sempre me apoiou, ajudou e ensinou tudo.

Ao meu voinho querido e amado que me ama demais e sempre foi exemplo de determinação e luta. Por isso tenho conseguido ânimo para chegar até aqui.

Ao Diego Gimenez Rocha, meu melhor amigo, meu namorado, meu companheiro e ajudador, que com sua sabedoria incrível sempre quer o meu bem e me ajudou até nas horas em que o que eu mais precisava era estar sozinha para estudar.

À minha melhor amiga, companheira das lutas, das tristezas e das alegrias Rafaela Quintanilha Abrahão, esta oportunidade veio por suas mãos e juntas aprendemos e amadurecemos demais nessa etapa da vida. Obrigada por me ajudar, pelos dias de perfusão, pelos vários dias de 12 horas seguidas no laboratório, pelo sorriso, pelo abraço, pelo companheirismo, por tudo. VAMO QUE DÁ!!!

À minha família que eu amo muito, meus primos, pastores, minha igreja, tios, vocês são meu alicerce e porto seguro, são parte de mim e compartilharam deste momento da minha vida. 
À minha amiga querida Adriana Teixeira Alves, companheira de lutas conquistas, amo muito você e te agradeço por todo o seu apoio durante mais esta fase da minha vida.

À minha orientadora Camila Squarzoni Dale, você sim é a principal responsável por todas as mudanças e aprendizados que obtive nessa fase. Hoje sou bem diferente do que fui ontem e amanhã serei mais diferente ainda, e grande parte desta mudança aconteceu porque com você aprendi muito não só da ciência, mas também da vida. Obrigada pela oportunidade.

À Dra. Rosana de Lima Pagano que foi muito solícita em me ajudar em momentos cruciais. Obrigada pelos seus ensinamentos "professora".

Ao Dr. Luiz que me concedeu a oportunidade de utilizar um espaço de pesquisa privilegiado no Instituto de Ensino e Pesquisa Hospital Sírio Libanês.

À Estefani Maique que me ajudou tremendamente, e também compartilhou de muitos momentos comigo e com a Rafa.

Ao Renato Andrade Paes que me ajudou imensamente em boa parte dos experimentos.

Ao Dr. Erich Fonoff por me ensinar e permitir que eu fizesse parte deste projeto.

À Paula de Seixas, Gislene Melo, Adriano, Elaine, Patrícia, Cristiane Ramos que contribuíram com meu projeto e me ajudaram.

Ao Ernande, Renato e Flávio por todo o apoio técnico nos experimentos com os animais, com certeza sem a ajuda e o auxilio de vocês meus resultados não seriam os mesmos.

Ao Prof ${ }^{\circ}$ Dr. Britto que me cedeu espaço em seu laboratório, e gentilmente por várias vezes se sentou ao meu lado e me ensinou.

Ao Adilson da Silva que me ajudou imensamente com sua grande experiência na parte técnica e me ajudou com detalhes importantes da vida. Muito Obrigada!!! 
À quase Dra. Carol Real e Isadora Furigo pela imensa ajuda nas minhas quantificações.

Ao Prof ${ }^{\circ}$ Dr. Newton Canteras que me acompanha desde minha entrada nesta etapa, obrigada por toda sua ajuda e disposição.

À Flávia Damasceno e a Hui-Tzu pessoas que me ajudaram muito. Foi muito bom o tempo em que convivemos.

Agradeço à Capes, à FAPESP e ao Hospital Sírio-Libanês pelo apoio financeiro sem o qual não seria possível trabalhar nesse projeto. 
"Tudo o que você tiver de fazer faça o melhor que puder, pois na sepultura, para onde você vai, não se faz nada, e ali não existe ciência, nem conhecimento, nem sabedoria."

\section{Eclesiastes 9:10}




\section{RESUMO}

França NRM. Estudo topográfico da analgesia induzida por estimulação elétrica transdural do córtex motor de ratos: somatotopia de resposta comportamental e perfil de ativação neuronal [dissertação (Mestrado em Ciências Morfofuncionais)]. São Paulo: Instituto de Ciências Biomédicas, Universidade de São Paulo; 2012.

A estimulação subliminar do córtex motor tem sido utilizada para o tratamento de pacientes com síndromes neuropáticas dolorosas resistentes a outros tratamentos convencionais. Dados obtidos por nosso grupo demonstram que a estimulação transdural do córtex motor (ECM) induz analgesia em ratos avaliados no modelo de pressão de pata, sendo este efeito dependente de opióides. Ainda, a ECM reverte a hiperalgesia mecânica e alodínia induzidas por neuropatia periférica em ratos. $O$ presente estudo investigou a topografia do efeito antinociceptivo induzido pela ECM bem como o padrão de ativação neuronal na coluna posterior da medula espinal (CPME) e na PAG pela expressão dos proto-oncogenes $c$-fos e egr-l avaliada por imunohistoquímica. Ratos foram submetidos à cirurgia para implante de eletrodos transdurais posicionados sobre quatro áreas distintas do córtex motor correspondentes à: pata anterior, pata posterior, vibrissas e cauda, determinadas de acordo com mapeamento cortical realizado previamente por nosso grupo e após 1 semana foram submetidos a sessões de estimulação cortical (15 min, $60 \mathrm{~Hz}, 210 \mu \mathrm{s} 1,25 \mathrm{~mA})$. Ao final de cada sessão, ainda sob estimulação, os animais foram avaliados em quatro testes comportamentais para determinação do limiar nociceptivo: teste de pressão da pata posterior, limiar de dor mecânica da pata anterior aferida com monofilamentos de von Frey, limiar de dor das vibrissas por Von Frey eletrônico e pinçamento da cauda. Animais onde nenhuma intervenção cirúrgica foi realizada (grupo branco) e animais que tiveram a intervenção cirúrgica, porém não foram estimulados (grupo não estimulado) foram submetidos aos mesmos protocolos experimentais e avaliados como grupos controle. Os resultados obtidos demonstram que a ECM induz antinocicepção nos animais, sendo que o aumento do limiar nociceptivo é observado exclusivamente no membro correspondente à área do córtex motor estimulada em cada grupo experimental. Com relação ao padrão de imunoreatividade observou-se uma diminuição significativa da expressão das proteínas Fos e Egr-1 nas lâminas superiores da CPME para cada grupo avaliado e um aumento desta expressão na PAG. Os dados obtidos demonstram que a analgesia induzida pela estimulação do córtex motor de ratos tem efeito topográfico, específico e correspondente à área do córtex motor estimulada e este efeito envolve a inibição da CPME e ativação do sistema de analgesia endógeno.

Palavras-chave: Estimulação elétrica. Córtex motor. Analgesia. 


\begin{abstract}
França NRM. Topographical evaluation of the analgesic effect induced by transdural electrical stimulation of the motor cortex of rats: somatotopy of behavioral response and profile of neuronal activation [Masters thesis (Morphofunctional Science)]. São Paulo: Instituto de Ciências Biomédicas, Universidade de São Paulo; 2012.

Subliminal stimulation of the motor cortex has been used to treat patients with neuropathic pain syndromes resistant to other conventional treatments. Data obtained by our group demonstrates that transdural electrical stimulation of the motor cortex (MCS) induces opioid-dependent analgesia in rats evaluated by the paw pressure test. Also, MCS reverses mechanical hyperalgesia and allodynia induced by a peripheral neuropathy in rats. The present study investigates the topography of the antinociceptive effect induced by MCS as well as the pattern of neuronal activation evaluated by Fos and Egr-1 immunolabel in the dorsal horn of the spinal cord (DHSC) and in the periaqueductal gray (PAG). Rats underwent surgery for implantation of transdural electrodes positioned on four distinct areas of the corresponding motor cortex: fore limb, hind limb, whiskers and tail, determined in accordance with cortical mapping carried out by our group and one week after the surgery were submitted to cortical stimulation sessions $(15 \mathrm{~min}, 60 \mathrm{~Hz}, 210 \mu \mathrm{s} 1.25 \mathrm{~mA})$. At the end of each session, but still under stimulation, animals were evaluated in four behavioral tests to determine the nociceptive threshold: paw pressure test of hind paw, mechanical pain threshold of the fore limb evaluated by von Frey microfilaments, nociceptive threshold of the whiskers evaluated by electronic von Frey and tail pinch test. Animals in which no surgery was performed (naive group) and animals that underwent the surgery, but were not stimulated (no stimulated group) were submitted to the same experimental protocols and evaluated as control groups. Results obtained so far demonstrate that MCS induces antinociception in rats and the increase in the nociceptive threshold is observed exclusively in the limb area corresponding to the stimulated motor cortex in each experimental group. Regarding the pattern of immunoreactivity, a significant decrease in Fos and Egr-1 expression was observed in the DHSC superficial laminae for all the groups of animals implanted and an increased expression in the PAG. Data obtained herein demonstrate that the analgesia induced by MCS in rats has topographic effect, specific and relevant to the stimulated area of motor cortex. Also, this effect involves the inhibition of DHSC and activation of descending pain inhibitory systems.
\end{abstract}

Keywords: Electrical stimulation. Motor cortex. Analgesia. 


\section{LISTA DE ILUSTRAÇÕES}

Figura 1 - Coordenadas estereotáxicas para implante dos eletrodos nas áreas do córtex motor......................................................................... 28

Figura 2 - $\quad$ Ilustração do teste de pressão da pata.............................................. $\quad 30$

Figura 3 - Ilustração do teste de estimulação táctil por monofilamentos de von

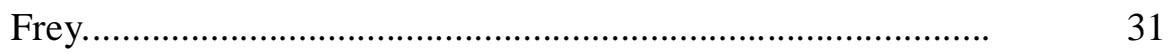

Figura 4 - Ilustração da pinça utilizada no teste de pinçamento da cauda............ 32

Figura 5 - $\quad$ Ilustração do teste de alodínia mecânica por von Frey eletrônico....... 32

Figura 6 - Efeito da ECM, na área correspondente às vibrissas, sobre o limiar nociceptivo de ratos.............................................................. $\quad 36$

Figura 7 - Efeito da ECM, na área correspondente à pata anterior sobre o limiar nociceptivo de ratos.............................................................. 37

Figura 8 - Efeito da ECM, na área correspondente à cauda, sobre o limiar nociceptivo de ratos.............................................................. 38

Figura 9 - Efeito da ECM, na área correspondente à pata posterior sobre o limiar nociceptivo de ratos.

Figura 10 - Quantificação da marcação neuronal pela expressão de Fos na medula espinal.

Figura 11 - Quantificação da marcação neuronal pela expressão de Fos nas Lâminas superficiais (I-IV) e profundas (V e VI) da CPME

Figura 12 - Fotomicrografia representativa de secções da coluna posterior da medula espinal (lado direito) submetidas à imunohistoquímica para Fos

Figura 13 - Quantificação da marcação neuronal pela expressão de Egr-1 na medula espinal

Figura 14 - Quantificação da marcação neuronal pela expressão de Egr-1 nas Lâminas superficiais (I-IV) e profundas (V e VI) da CPME.

Figura 15 - Fotomicrografia representativa de secções da coluna posterior da medula espinal (lado direito) submetidas à imunohistoquímica para

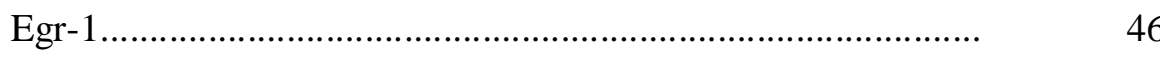

Figura 16 - Quantificação da marcação neuronal pela expressão de Fos na PAG.. 48 
Figura 17 - Quantificação da marcação neuronal pela expressão de Fos na PAG de animais implantados na região do córtex motor correspondente à Pata Posterior

Figura 18 - Fotomicrografia de secções da PAG submetidas à imunohistoquímica para Fos de ratos implantados na região do córtex motor correspondente à Pata Posterior

Figura 19 - Quantificação da marcação neuronal pela expressão de Fos na PAG de animais implantados na região do córtex motor correspondente à Pata Anterior.

Figura 20 - Fotomicrografia de secções da PAG submetidas à imunohistoquímica para Fos de ratos implantados na região do córtex motor correspondente à Pata Anterior.

Figura 21 - Quantificação da marcação neuronal pela expressão de Fos na PAG de animais implantados na região do córtex motor correspondente à Cauda.

Figura 22 - Quantificação da marcação neuronal pela expressão de Egr-1 na PAG

Figura 23 - Quantificação da marcação neuronal pela expressão de Egr-1 na PAG de animais implantados na região do córtex motor correspondente à Pata Posterior

Figura 24 - Fotomicrografia de secções da PAG submetidas à imunohistoquímica para Egr-1 de ratos implantados na região do córtex motor correspondente à Pata Posterior

Figura 25 - Quantificação da marcação neuronal pela expressão de Egr-1 na PAG de animais implantados na região do córtex motor correspondente à Pata Anterior.

Figura 26 - Fotomicrografias de secções da PAG submetidas à imunohistoquímica para Egr-1 de ratos implantados na região do córtex motor correspondente à Pata Anterior.

Figura 27 - Quantificação da marcação neuronal pela expressão de Egr-1 na PAG de animais implantados na região do córtex motor correspondente à Cauda. 


\section{LISTA DE ABREVIATURAS E SIGLAS}

\begin{tabular}{|c|c|}
\hline ANOVA & Análise de variância \\
\hline ATP & Adenosina trifosfato \\
\hline Bco & Grupo branco de animais \\
\hline BNDF & Fator neurotrófico derivado do encéfalo \\
\hline CEUA & Comissão de Ética para o Uso de Animais \\
\hline CPME & Coluna Posterior da Medula Espinal \\
\hline ECM & Estimulação do Córtex Motor \\
\hline e.p.m & Erro padrão da média \\
\hline Est & Grupo Estimulado de animais \\
\hline Fig. & figura \\
\hline FL & Fore limb \\
\hline $\mathrm{g}$ & grama \\
\hline $\mathrm{HL}$ & Hind limb \\
\hline $\mathrm{Hz}$ & Hertz \\
\hline IASP & Associação Internacional para o Estudo da Dor \\
\hline IEG & Immediate-early gene \\
\hline i.p. & Intraperitoneal \\
\hline M & Molar \\
\hline $\mathrm{mA}$ & miliAmpère \\
\hline MI & Medida inicial \\
\hline $\min$. & minuto \\
\hline $\mathrm{mL}$ & mililitro \\
\hline $\mathrm{mm}$ & milímetro \\
\hline mRNA & RNA mensageiro \\
\hline Nadr & Noradrenalina \\
\hline NMDA & N-metil D-Aspartato \\
\hline $\mathrm{NE}$ & Grupo Não Estimulado de animais \\
\hline PAG & Substância cinzenta periaquedutal \\
\hline PB & Tampão fostato \\
\hline PBS & Salina tamponada \\
\hline PVG & Substância Cinzenta Periventricular \\
\hline
\end{tabular}




$\begin{array}{ll}\text { s } & \text { Segundos } \\ \text { S-I } & \text { Córtex sensorial primário } \\ \text { S-II } & \text { Córtex sensorial secundário } \\ \text { SN } & \text { Sistema Nervoso } \\ \text { SNC } & \text { Sistema Nervoso Central } \\ \text { SP } & \text { Substância P } \\ \text { T } & \text { Tail } \\ \text { VPL } & \text { Núcleo talâmico ventral póstero-lateral } \\ \text { VPM } & \text { Núcleo talâmico ventral póstero-medial } \\ \text { W } & \text { Whiskers } \\ \mu \text { L } & \text { Microlitro } \\ \mu \mathrm{m} & \text { micrômetro } \\ \mu \mathrm{s} & \text { Microssegundo } \\ 5 \mathrm{HT} & \text { serotonina } \\ 5 \mathrm{HT} 1 \mathrm{~A} & \text { receptor de serotonina tipo 1 A }\end{array}$




\section{SUMÁRIO}

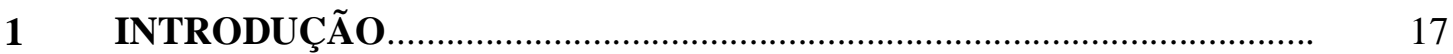

1.1 Transmissão do impulso nociceptivo............................................................

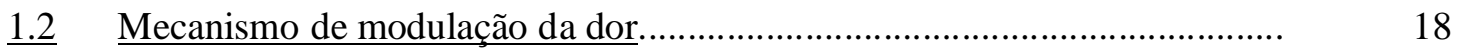

1.3 Estimulação do córtex motor e Analgesia......................................................... 20

1.4 Marcação neural e nocicepção...................................................................... 21

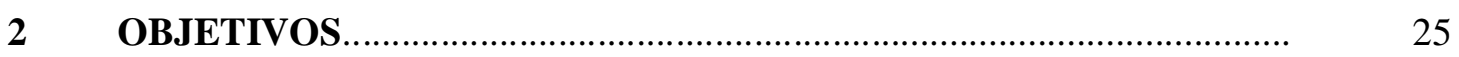

3 MATERIAIS E MÉTODOS................................................................. 26

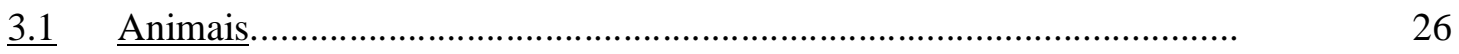

3.2 Procedimento cirúrgico para implantação dos eletrodos...................................... 26

3.3 Estimulação elétrica..................................................................................

3.4 Avaliação comportamental do mapeamento por meio de ensaios in vivo de avaliação da sensibilidade dolorosa................................................................ 29

3.4.1 Teste de pressão da pata...................................................................

3.4.2 Hiperalgesia mecânica por filamentos de von Frey.......................................... $\quad 30$

3.4.3 Teste de pinçamento da cauda.................................................................

3.4.4 Alodinia Mecânica por von Frey eletrônico...................................................... 32

3.5 Imuno-histoquímica..........................................................................

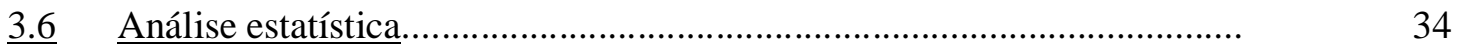

$4 \quad$ RESULTADOS ........................................................................

4.1 Efeito da ECM sobre a Somatotopia do córtex motor......................................... 35

4.2 Efeito da ECM sobre a ativação neuronal de áreas envolvidas na transmissão nociceptiva....................................................................................

4.2.1 Efeito da ECM sobre a ativação neuronal na CPME...................................... 40

4.2.2 Efeito da ECM sobre a ativação neuronal na PAG.......................................... 47

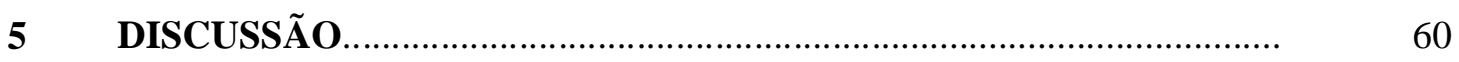

6 CONCLUSÃO

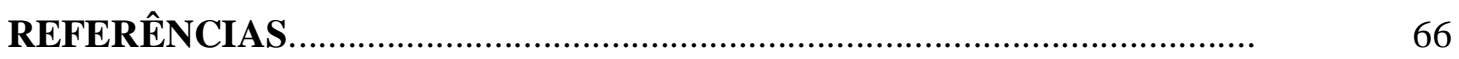




\section{INTRODUÇÃO}

\subsection{Transmissão do impulso nociceptivo}

A Associação Internacional para o Estudo da Dor (IASP) definiu, em 1986, dor como "uma experiência sensorial e emocional desagradável associada a lesões reais ou potenciais". Uma das funções vitais do sistema nervoso é prover informações sobre a ocorrência ou perigo de lesões. A sensação de dor, pela sua natureza inerente, contribui para essa função (Raja et al., 1999).

O início da propagação da dor é dado pela geração de potenciais de ação nas fibras aferentes primárias de pequeno diâmetro, classificadas como fibras $\mathrm{C}$ e $\mathrm{A} \delta$, que possuem receptores específicos para a dor, denominados nociceptores. Os nociceptores são normalmente ativados por estímulos de intensidade lesiva de origem mecânica, térmica ou química (Almeida et al., 2004; Riedel, Neeck, 2001). Os neurônios aferentes primários, uma vez ativados, fazem conexões, diretas ou indiretas, com neurônios intrínsecos na coluna posterior da medula espinal (CPME) classificados como: a) neurônios de projeção, que levam a informação nociceptiva para centros superiores do cérebro; b) interneurônios excitatórios, que levam os impulsos sensoriais para os neurônios de projeção; ou c) interneurônios inibitórios, que regulam o fluxo de informação nociceptiva para os centros superiores (Jessel, 1991).

As fibras aferentes primárias fazem a transmissão sináptica com os neurônios da CPME por meio de neurotransmissores. Dentre as substâncias que medeiam a transmissão sináptica estão o glutamato, o fator neurotrófico derivado do encéfalo (BNDF), prostaglandinas, adenosina trifosfato (ATP) e neuropeptídeos como a substância P (SP) (Doubell, 1999). Na medula espinhal, a transmissão nociceptiva envolve ainda a participação de canais iônicos (Altier, Zamponi, 2004), expressos nos neurônios sensoriais, sendo que a ativação de alguns destes gera correntes que despolarizam ou hiperpolarizam a membrana celular causando excitação ou inibição neuronal. Os principais canais envolvidos nesse processo são os canais de sódio, os canais de cálcio dependentes de voltagem e os canais de potássio (Lee et al., 2005).

Da medula, a informação nociceptiva é levada para estruturas do tronco encefálico e diencéfalo, por diferentes vias ascendentes, pelos neurônios de projeção (Millan, 1999). Dentre as principais projeções supraespinais da via nociceptiva estão os tratos espinomesencefálico, espinoreticular, espino-hipotalâmico e espinotalâmico, 
sendo este último o mais proeminente na condução do impulso nocivo (Jessel, 1991). A via espinotalâmica projeta-se para os núcleos talâmicos ventral póstero-lateral (VPL) e ventral póstero-medial (VPM), envolvidos com os componentes discriminativos da sensibilidade dolorosa e para os núcleos talâmicos inespecíficos (centromedial, centrolateral, láterocentral e intralaminares), relacionados com os componentes afetivos da dor.

No tálamo ocorre a recepção, integração e transferência do potencial nociceptivo para o córtex cerebral, onde a informação pode ser somatotopicamente organizada (Craig, Dostrovsky,1999). Baseando-se em critérios funcionais, as principais regiões corticais envolvidas na resposta dolorosa são os córtices sensorial primário (S-I), secundário (S-II) e motor (Bromm, Treede, 1987; Schnitzler, Ploner, 2000). Entretanto, foi observado que pacientes com lesões cerebrais específicas, particularmente no córtex S-I, são ainda capazes de sentir dor (Brooks, Tracey, 2005). Desta maneira a relevância dessas regiões corticais durante a percepção da resposta nociceptiva ainda permanece sem ser elucidada.

\subsection{Mecanismo de modulação da dor}

O conceito de modulação ou supressão de dor por mecanismos endógenos advém de observações realizadas em indivíduos ou animais que em situações de "luta ou fuga" aparentavam não sentir dor, mesmo quando ocorriam lesões teciduais importantes (Amit, Galina, 1986; Terman et al., 1984). As primeiras evidências concretas sobre a existência de sistemas supraespinais controladores das vias sensitivas foram apresentadas na década de 1950 (Lindblom, Ottonsson, 1957) sendo a apresentação da "Teoria de Comporta" por Melzack e Wall (1965) um marco importante na conceituação sobre a existência de sistemas moduladores específicos na CPME.

A importância das influências suprassegmentares no processamento da dor na medula espinhal foi demonstrada quando se verificou que os neurônios da lâmina $\mathrm{V}$ da CPME tornavam-se hipersensíveis à estimulação nociceptiva em animais descerebrados, indicando que estruturas encefálicas, provavelmente da formação reticular do tronco encefálico, exercem atividade inibitória ou modulatória nos neurônios segmentares (Basbaum et al., 1976; Loeser et al., 1968). Ainda, a contribuição dos sistemas rostrocaudais na modulação da dor foi confirmada pela demonstração de que a 
estimulação elétrica de regiões limitadas da substância cinzenta periaquedutal mesencefálica (PAG) em animais, resultava em analgesia sem comprometer outras modalidades e qualidades sensitivas (Reynolds, 1969), sendo este fenômeno associado à depressão da atividade dos neurônios das lâminas I e V da CPME (Duggan et al., 1981; Nathan, 1977).

A PAG recebe aferências de diferentes origens como da substância cinzenta periventricular (PVG); córtices frontal, parietal e insular; amígdala; núcleos parafascicular do tálamo, cuneiforme e do loco cerúleo, formação reticular pontobulbar e CPME. Esta região projeta-se para núcleos do bulbo ventromedial implicados no mecanismo de supressão da dor, destacando-se o núcleo magno da rafe, os neurônios da formação reticular ventral e o núcleo reticular gigantocelular que recebem projeções oriundas também, do hipotálamo posterior e de neurônios dos núcleos serotoninérgicos do encéfalo; noradrenérgicos do bulbo, ponte e reticular gigantocelular dorsolateral (Mason, 2001; Rosenfeld, 1994; Sandkuhler, 1996; Vanegas, Schaible, 2004).

A estimulação da PAG inibe o núcleo gigantocelular (Gauriau, Bernard, 2002; Krout et al., 2002). Nesse sentido, foi demonstrado que tanto a estimulação elétrica quanto a administração de morfina nesta estrutura produzem analgesia pela ativação de tratos rostrocaudais inibitórios (Dewey et al., 1969) sendo este efeito seguido de tolerância em ambas as manipulações (Falconer, 1953; Mayer et al., 1971). Ainda, a injeção de morfina na região induz aumento da atividade celular do núcleo magno da rafe (Oleson, Liebeskind, 1975). Foram também comprovadas projeções inibitórias oriundas dos núcleos bulbares ventromediais, trafegando pelo quadrante dorsolateral da medula espinhal e projetando-se nas lâminas superficiais da CPME (Basbaum, Fields, 1979).

As vias rostrocaudais que se projetam nas lâminas superficiais da CPME utilizam serotonina (5HT), noradrenalina (Nadr) e SP como neurotransmissores (Basbaum, Fields, 1979; Jones, 1991). A via serotoninérgica está envolvida no efeito analgésico da morfina administrada no tronco encefálico e no mecanismo da analgesia induzida pela estimulação elétrica do tronco encefálico (Suzuki et al., 2004). Foi também demonstrado que fibras rostrocaudais catecolaminérgicas inibitórias, oriundas do bulbo, projetam-se nas unidades nociceptivas da CPME, principalmente nas lâminas I, II e X e atuam via receptores $\alpha-2$ (Jones, 1991), mediante a liberação de GABA e glicina ou, indiretamente, via tratos serotoninérgicos (Suzuki et al., 2004). 
As vias originadas no núcleo reticular paragigantocelular contêm neurônios encefalinérgicos e serotoninérgicos, sendo que alguns deles recebem projeções da PAG, projetando-se para CPME via funícolo dorsolateral utilizando Nadr com atividade inibitória (Beitz et al., 1983).

\section{$\underline{1.3 \text { Estimulação do córtex motor e Analgesia }}$}

Desde a descrição realizada por Tsubokawa et al., em 1990, de que a estimulação do córtex motor (ECM) cerebral gerava analgesia, esta modalidade de tratamento ganhou muito destaque, especialmente no tratamento da dor neuropática crônica. Estes autores basearam-se em investigações preliminares sobre a estimulação cortical motora (Lindblom, Ottosson, 1957; Penfield, Perot, 1963) e sugeriram que os estímulos elétricos inibiam neurônios nociceptivos desaferentados do córtex cerebral sensitivo e que a inibição dos neurônios talâmicos hiperativos apenas era observada quando era estimulado o córtex localizado anteriormente ao córtex sensitivo, ou seja, o córtex motor primário (Tsubokawa et al., 1991). Na clínica médica, a técnica tem se demonstrado eficiente para o tratamento de pacientes com dor neuropática trigeminal (Lefaucheur et al., 2001, 2009; Meyerson et al., 1993; Nguyen et al., 1997), dor por desaferentação (Tsubokawa et al., 1993), e em diversos tipos de dor refratária (Lefaucheur et al., 2009; Nuti et al., 2005).

Exames de imagem (PET-scan) demonstram que a ECM aumenta o fluxo sanguíneo em várias áreas corticais e subcorticais, incluindo o tálamo ipsilateral, o giro do cíngulo, o córtex orbitofrontal, a PAG e o tronco encefálico, mas não ativa o córtex sensitivo e as vias motoras caudais ao local da estimulação, com exceção do tálamo ipsilateral (Cruccu et al., 1997; Garcia-Larrea et al., 1999). Em doentes com dor central decorrente de enfarto encefálico e déficit motor discretos ou mais pronunciado foram observados resultados distintos frente a ECM, tendo sido o alívio da dor de mais de $60 \%$ em $72 \%$ dos doentes sem déficit motor ou quando este era muito discreto (Katayama et al., 1998). Porém, a integridade do córtex sensitivo e do sistema lemniscal, entretanto, não constitui condição necessária para que a estimulação do córtex motor induza alívio da dor, uma vez que já foi demonstrado que o enfarto do lobo parietal, incluindo o do córtex S-I, não compromete o grau de melhora (Nguyen et al., 2000). 
Foi postulado por Tsubokawa e colaboradores $(1991,1993)$, frente ao tratamento da dor central, que tanto a estimulação elétrica talâmica (cerebral profunda), como a do córtex sensorial, são geralmente menos efetivas que a ECM. Corroborando com esta idéia, foi demonstrado pelo nosso grupo, que a estimulação epidural do córtex somatosensorial, na área correspondente a pata posterior do animal, não interfere com o limiar nociceptivo de ratos avaliados no teste de pressão da pata (Fonoff et al., 2009a).

Experimentalmente, foi demonstrado que a ECM induz antinocicepção contralateral no modelo da pressão de pata de animais desaferentados, mas não na resposta nociceptiva dos animais no teste de reflexo de retirada da cauda (Rusina et al., 2005). De acordo com pesquisas que utilizaram métodos eletrofisiológicos, a inibição da atividade de neurônios da CPME gerado por estímulos mecânicos reduz-se durante a estimulação tanto do córtex S-I quanto do motor, efeito que desaparece após o término do período da estimulação sugerindo que a inibição da atividade neuronal na CPME seria responsável pelo efeito antinociceptivo decorrente da estimulação do córtex motor (Kuroda et al., 2000; Senapati et al., 2005a, b). Foi também demonstrado que a estimulação elétrica no córtex pré-frontal medial resulta em analgesia em animais avaliados no teste de placa quente e reflexo de retirada da cauda (Hardy, 1985). Ainda, o registro de atividade neuronal na PAG sugere que há participação do sistema supressor de dor rostrocaudal neste mecanismo (Hardy, Haigler, 1985). A ECM induz diminuição do limiar de dor tanto em animais desaferentados quanto em animais com dor neuropática induzida por modelo de dor crônica periférica (Rusina et al., 2005; Vaculín et al., 2008).

Embora seja uma técnica bastante utilizada na clínica médica, pouco se sabe sobre os mecanismos envolvidos na analgesia induzida pela ECM. Nesse sentido, tem sido proposto que o efeito analgésico observado seja decorrente de uma inibição da atividade neuronal, principalmente dos neurônios da CPME (Kuroda et al., 2000; Senapati et al., 2005a, b). Resultados do nosso grupo demonstram que a ECM induz antinocicepção em ratos normais ou submetidos ao modelo de dor neuropática e avaliados no modelo de pressão da pata, sem interferir com a resposta motora destes animais (Fonoff et al., 2009a; Pagano et al., 2011). Ainda, a antinocicepção induzida em animais normais é mediada por receptores opióides (Fonoff et al., 2009a). Em animais com dor neuropática tratados com a técnica já foi demonstrada pouca contribuição da via noradrenérgica do lócus cerúleos no efeito antinociceptivo (Viisanen, Pertovaara, 
2010a), e a participação da via descendente serotoninérgica atuando por meio dos receptores 5HT1A da medula nesta antinocicepção (Viisanen, Pertovaara, 2010b).

Dados obtidos por nosso grupo demonstraram que a ECM induz analgesia em ratos com dor neuropática por induzir ativação do sistema límbico e da via descendente de dor demonstrado pelo aumento da expressão de proteína Fos na PAG, no córtex cingulado anterior e nos núcleos central e basolateral da amígdala (Pagano et al., 2011). Há indícios de que o efeito da estimulação cortical no tratamento da dor tem relação com a somatotopia do córtex motor (Canavero, Bonicalzi, 1995), uma vez que foi sugerido que a estimulação do córtex motor induz analgesia, via ativação de neurônios não-nociceptivos que estabelecem conexões recíprocas entre os córtices motor e sensitivo, restaura os mecanismos inibitórios que atuam em neurônios nociceptivos corticais hiperativos (Tsubokawa, Katayama, 1998).

\subsection{Marcação neural e nocicepção}

A expressão de proto-oncogenes, tem sido extensivamente avaliada no sistema nervoso para o mapeamento de ativação das vias neuronais. Estes genes são definidos por rápida indução transcricional e dentre os que são mais utilizados como marcadores de mudanças na atividade neuronal se encontram os genes egr-1 (krox-24, zif268 ou zenk), c-fos e c-jun ( Beckmann, Wilce, 1997; Herrera, Robertson, 1996; Morgan, Curran, 1989; Sagar et al., 1988).

A descoberta do gene $c$-fos e de seu produto de transcrição, a proteína Fos no sistema nervoso central após estimulação nociva periférica (Hunt et al., 1987) tornou possível buscar informações sobre as vias neurais envolvidas na nocicepção, e sua expressão tem sido utilizada no mapeamento de vias nociceptivas e na investigação dos fatores que modulam suas atividades (Harris, 1996; Herdegen, Leah, 1998). A literatura demonstra que estímulos nocivos de natureza mecânica, química ou térmica do membro posterior ou da cauda ou ainda a estimulação elétrica de fibras do tipo $\mathrm{C}$ do membro posterior de ratos, resultam em distribuição bilateral similar de células imunorreativas à proteína Fos em diversas regiões do SNC (Bullit, 1990; Hermanson, Blomqvist, 1996). Sua expressão tem início entre 1 e 2 horas após o estímulo, e atinge um pico após 2 horas nas lâminas I e II da medula espinhal, ipsilateralmente à estimulação nociva (Hunt et al., 1987). Depois de decorridas 8 horas do estímulo é possível observar uma marcação nas lâminas profundas V, VI, VII e X com um pico após 16 horas. Ainda a 
distribuição de Fos no cérebro ocorre de maneira similar ao que é considerado o sistema central da dor, após diferentes estímulos nociceptivos (Bullit, 1989,1990; Harris, 1996; Honkaniemi, 1992; Lanteri-Minet, 1993; Pertovaara et al., 1993).

Frente à resposta nociceptiva em ratos, foi demonstrada a expressão de Fos, Jun e Egr em neurônios da CPME submetidos à estimulação química ou térmica nociva, onde a indução destes genes está relacionada com as alterações que ocorrem em resposta ao estímulo doloroso (Hunt et al., 1987). Ainda, o aumento da expressão de Fos, é observado em diferentes áreas do encéfalo e medula espinal, tanto após estimulação elétrica de fibras nociceptivas quanto após a indução de inflamação aguda e crônica (Buritova et al., 1995; Herdegen et al., 1991; Lanteri-Minet et al., 1993). Também é sugerida uma correlação direta entre nocicepção e expressão de Fos uma vez que a antinocicepção, via opióides, observada no teste da formalina, é acompanhada proporcionalmente da inibição de Fos na medula espinal (Gogas et al., 1991). Neste sentido, foi demonstrado que a expressão de Fos na medula espinal é inibida por manipulações que produzem analgesia, como estimulação elétrica do núcleo magno da rafe e eletroacupuntura (revisto por Morgan, Curran, 1989). Ainda, sua expressão em neurônios espinais, frente à estimulação nociva periférica, é suprimida por drogas analgésicas e modulada por NMDA e óxido nítrico sintase (Harris, 1998). Foi também demonstrado que a estimulação elétrica do córtex S-II induz antinocicepção e reduz o número de neurônios que expressam Fos nas camadas superficiais da CPME em animais submetidos ao teste da formalina (Gojyo et al., 2002; Kuroda et al., 2001),

Ainda, foi demonstrado que estímulos dolorosos de diferentes origens e intensidades induzem respostas distintas no que se refere à expressão Fos em diferentes áreas do SN. Nesse sentido, observou-se que a expressão de Fos ocorre de maneira distinta nas colunas lateral ou dorsal da PAG e em diferentes áreas da medula espinhal, dependendo do tipo e intensidade de estímulo doloroso aplicado (Keay, Bandler, 1993; Keay et al., 2001; Lumb, 2002) foi também demonstrada somatotopia na expressão de Fos em diferentes áreas da medula espinhal frente a estimulação nociva em diferentes áreas do mesmo membro (Aloisi et al., 1993; Bullitt, 1991; Mineta et al., 1995). 
Apesar do avanço de nossa compreensão acerca dos mecanismos de ação do efeito analgésico da estimulação do córtex motor primário, muitas questões permanecem abertas. Em primeiro lugar, não sabemos se o efeito analgésico da estimulação é completamente dependente da topografia da representação motora no córtex cerebral. Dados de pacientes com dor neuropática indicam haver relação topográfica entre a área do córtex motor e o segmento acometido pela dor. No entanto, não há estudos comparativos de alvos não relacionados topograficamente. Não se sabe se o efeito analgésico da estimulação de uma determinada área cortical é capaz de alterar o limiar de dor em regiões adjacentes do corpo. Também não sabemos se há um gradiente de efeito, ou seja, se regiões do corpo mais próximas à estimulada apresentariam um efeito analgésico que decresceria progressivamente ao se distanciar da região alvo em direção a partes mais distantes do corpo. Tais informações tem relevância aplicada, pois possivelmente determinariam realmente qual o foco de estimulação com maior efeito e também sobre a extensão do efeito, pois há casos de dores que se estendem sobre uma região corporal grande, mas em que se deve escolher uma área alvo única para a estimulação.

Ainda, embora a utilização de estimulação do córtex para indução de analgesia seja uma técnica bastante aplicada na medicina, pouco se sabe sobre os mecanismos que envolvem este efeito, daí a necessidade de estudos que se aprofundem nesse campo.

Deste modo consideramos relevante o refinamento deste conceito com o estudo da topografia do efeito antinociceptivo e sua relação com a atividade dos núcleos subcorticais relacionados com a codificação e modulação da dor e seus e possíveis mecanismos de ação. Para tal, foi utilizado o mapeamento funcional do córtex peribregmático em animais submetidos a modelos comportamentais de avaliação da sensibilidade dolorosa e com isso, as diferentes áreas corticais correspondentes a cada segmento corporal foram estimuladas sendo avaliado o efeito analgésico de cada uma destas subáreas motoras e a localização do efeito antinociceptivo correspondente. 


\section{OBJETIVOS}

i. Desenvolver modelo animal para o mapeamento da topografia da analgesia induzida por estimulação elétrica do córtex motor peribregmático (ECM);

ii. realizar a avaliação comportamental do efeito da ECM sobre o mapeamento por meio de ensaios in vivo de avaliação da sensibilidade dolorosa;

iii. investigar padrão de ativação neuronal na coluna posterior da medula espinhal (CPME) e na substância cinzenta periaquedutal (PAG) frente à ECM nas diferentes áreas topográficas por imunohistoquímica; 


\section{MATERIAIS E MÉTODOS}

\section{$\underline{3.1 \text { Animais }}$}

Foram utilizados ratos Wistar machos, pesando entre 200-250 g. Os animais foram mantidos em local apropriado, com temperatura controlada $\left(22+/-2{ }^{\circ} \mathrm{C}\right)$, ciclo claro e escuro (12/12 horas), com livre acesso à água e ração por um período mínimo de três dias antes de serem utilizados nos experimentos. Os animais foram manipulados considerando-se os princípios e o guia de uso de animais de laboratório envolvendo dor e nocicepção (Zimmermann, 1983) e aprovado pela Comissão de Ética para o Uso de Animais (CEUA) do Hospital Sírio Libanês (protocolo de aprovação CEUA2009/02) e do Instituto de Ciências Biomédicas da Universidade de São Paulo (protocolo no 122 na fl. 93 do livro 02).

\subsection{Procedimento cirúrgico para implantação dos eletrodos}

Sob anestesia geral (Ketamina e Xilazina 1:1, $100 \mu \mathrm{L} / 100 \mathrm{~g}$; intramuscular) (Kober et al., 2005) associada a anestesia local do escalpo com lidocaína 2\% (100 $\mu \mathrm{L} /$ animal), ratos foram fixados ao aparelho estereotáxico por barras auriculares e presilhas maxilares. O escalpo e o periósteo foram afastados com uma incisão linear sagital expondo a superfície superior do crânio e permitindo a visibilização das suturas sagital, coronária e lambdóide que serviram de parâmetros para a localização estereotáxica dos alvos de implante das diferentes áreas a serem estudadas, segundo os mapas delimitados nos experimentos de mapeamento cortical (Fonoff et al., 2009b). Pequenas trepanações, com o diâmetro discretamente maior do que o diâmetro dos eletrodos foram realizadas com perfurador elétrico. A integridade da dura mater foi condição absoluta para a inclusão do animal no restante do protocolo. Os eletrodos foram, então, inseridos de forma delicada através das trepanações para apenas encostarem-se à superfície dural e logo após serem colados com resina acrílica polimerizante para fixação ao crânio. Uma outra trepanação distante da área em questão recebeu um parafuso de fixação ao crânio para auxiliar na fixação dos eletrodos ao crânio do animal. Os prolongamentos dos eletrodos foram inseridos em um soquete de forma padronizada para a ulterior conexão com os cabos do estimulador. O soquete também foi colado ao restante da resina fixada ao crânio, funcionando também como isolante elétrico dos contatos do soquete. Quando 
necessário, foram feitos alguns pontos de sutura na incisão e aplicada cola biológica de secagem rápida. Os eletrodos foram confeccionados em nosso laboratório com fios de aço inoxidável de diâmetro de $0,3 \mathrm{~mm}$ colocados lado a lado com capa isolante cobrindo a lateral de cada pólo, de modo que distassem $0,5 \mathrm{~mm}$ um do outro. Os animais foram mantidos em gaiolas apropriadas, por um período de 7 dias antes de serem submetidos aos testes comportamentais de nocicepção.

Em geral as coordenadas estereotáxicas, são dadas nos três eixos, $\mathrm{X}$ - latero lateral, Y - anteroposterior e Z - profundidade. Sempre devendo haver uma referência que é considerada o ponto zero nos três eixos, que no caso do protocolo adotado foi o Bregma, confluência entre as suturas sagital e coronal no crânio. Como os pontos escolhidos foram todos na superfície do córtex (eletrodos são epidurais), todas as coordenadas $\mathrm{Z}$ correspondem a 0 . Todas as coordenadas foram montadas para $\mathrm{o}$ hemisfério direito (olhando por trás da cabeça do animal e de cima para baixo) com cada área contendo dois eletrodos (um positivo e um negativo), uma vez que o protocolo utilizado refere-se à estimulação epidural, onde cada eletrodo tem uma coordenada (Fonoff et al., 2009b).

As coordenadas estereotáxicas para os eletrodos de implante nas áreas do córtex motor, correspondentes a Pata Posterior, Pata Anterior, Vibrissa e Cauda estão ilustradas abaixo. A figura 1 ilustra a posição de cada eletrodo que foi implantado em cada área do córtex motor, para cada área de avaliação sobre o mapa publicado por Fonoff et al. (2009b).

$\underline{\text { Pata Posterior }}$

$\begin{array}{cc}\text { Eletrodo A } & \text { Eletrodo } \mathrm{B} \\ \mathrm{Y}=0,5 \mathrm{~mm} \text { rostral } & \mathrm{Y}=0,75 \mathrm{~mm} \text { caudal } \\ \mathrm{X}=1,25 \mathrm{~mm} \text { lateral } & \mathrm{X}=1,25 \mathrm{~mm} \text { lateral } \\ \mathrm{Z}=0 & \mathrm{Z}=0\end{array}$

\section{Pata Anterior}

Eletrodo A

Eletrodo B

$$
\begin{array}{cc}
\mathrm{Y}=1,5 \mathrm{~mm} \text { rostral } & \mathrm{Y}=1,5 \mathrm{~mm} \text { rostral } \\
\mathrm{X}=2,25 \mathrm{~mm} \text { lateral } & \mathrm{X}=3,25 \mathrm{~mm} \text { lateral } \\
\mathrm{Z}=0 & \mathrm{Z}=0
\end{array}
$$




\section{Vibrissa}

Eletrodo A

$$
\begin{aligned}
& \mathrm{Y}=3,5 \mathrm{~mm} \text { rostral } \\
& \mathrm{X}=1,25 \mathrm{~mm} \text { lateral }
\end{aligned}
$$$$
\mathrm{Z}=0
$$

Eletrodo B

$\mathrm{Y}=2,75 \mathrm{~mm}$ rostral

$\mathrm{X}=1,25 \mathrm{~mm}$ lateral

$\mathrm{Z}=0$

\section{$\underline{\text { Cauda }}$}

\section{Eletrodo A}

$$
\begin{aligned}
& \mathrm{Y}=1,5 \mathrm{~mm} \text { caudal } \\
& \mathrm{X}=0,50 \mathrm{~mm} \text { lateral }
\end{aligned}
$$

$$
\mathrm{Z}=0
$$

\section{Eletrodo B}

$\mathrm{Y}=2,25 \mathrm{~mm}$ caudal

$X=0,50 \mathrm{~mm}$ lateral

$$
\mathrm{Z}=0
$$

Figura 1 - Coordenadas estereotáxicas para implante dos eletrodos nas áreas do córtex motor

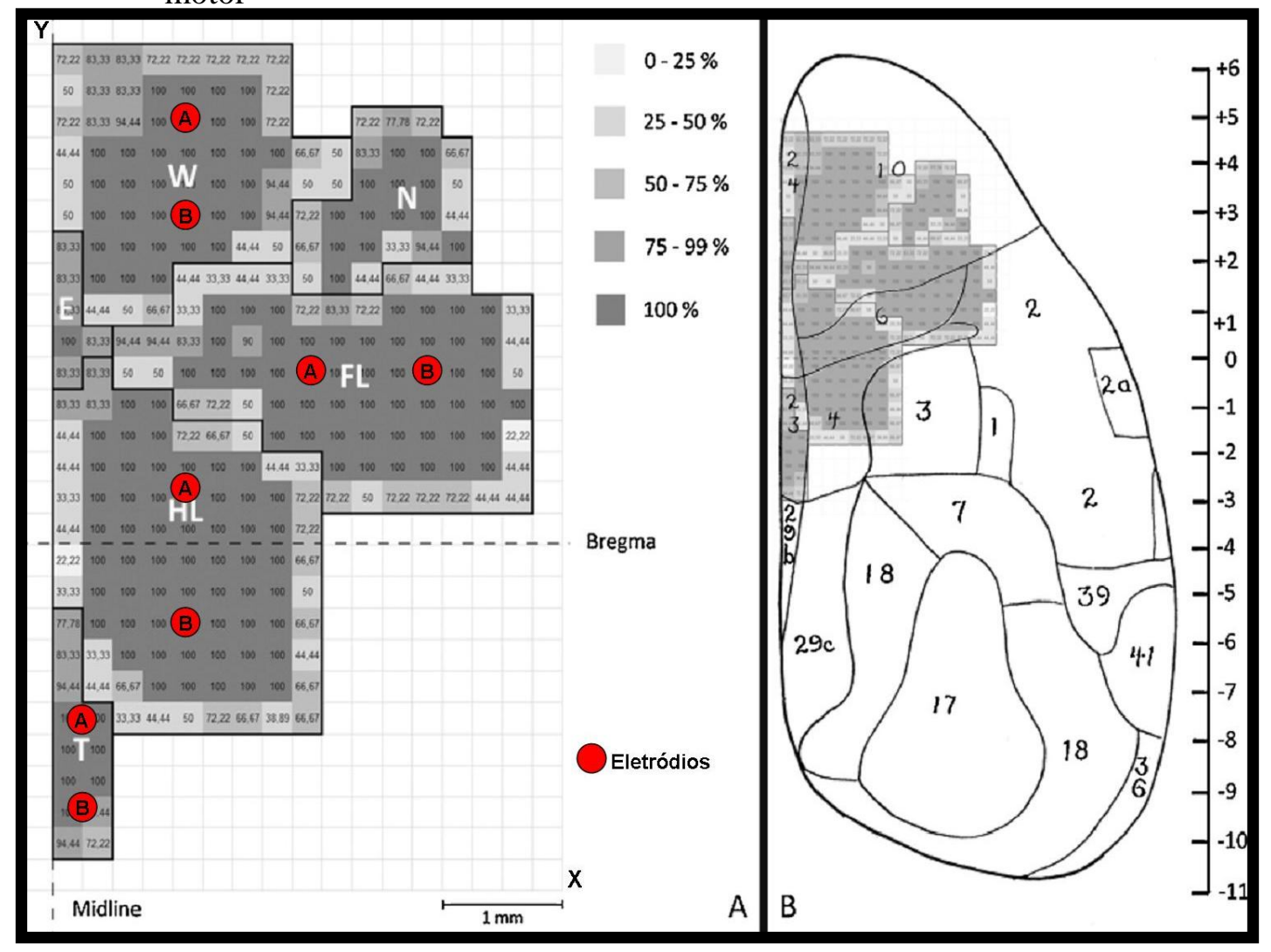

Coordenadas estereotáxicas para implante dos eletrodos nas áreas W (whiskers) - vibrissas, FL (fore limb) - pata anterior, HL (hind limb) - pata posterior e T (tail) - cauda.

Fonte: Adaptado de Fonoff et al., 2009b. 


\section{$\underline{3.3 \text { Estimulação elétrica }}$}

Uma semana após a implantação dos eletrodos os animais foram submetidos a sessões de estimulação cortical. O protocolo já padronizado por nosso grupo em ratos (Fonoff et al., 2009a) foi novamente utilizado e adequado aos eletrodos bipolares que promoveram uma estimulação mais circunscrita em cada área de interesse. Os parâmetros foram, frequiência de $60 \mathrm{~Hz}$, duração de pulso de $210 \mu$ s e amperagem de 1,25 mA em sessões de estimulação de 15 minutos. Ao final deste período, porém ainda sob estimulação, os testes nociceptivos foram aplicados. Para o projeto utilizou-se três grupos experimentais: Grupo Branco (Bco), que são animais que não sofreram nenhuma intervenção cirúrgica, porém foram avaliados nas mesmas condições dos demais animais; Grupo Não Estimulado (NE), sendo composto de ratos submetidos à cirurgia de implante, porém sem estimulação elétrica; e o Grupo Estimulado (Est) são os animais que receberam o implante e a estimulação elétrica.

\subsection{Avaliação comportamental do mapeamento por meio de ensaios in vivo de avaliação} da sensibilidade dolorosa

Para avaliar a somatotopia da analgesia induzida por estimulação do córtex motor escolheu-se 4 grupos distintos de estimulação. Cada grupo recebeu implante em uma das 4 regiões do córtex motor correspondentes à pata posterior, pata anterior, cauda e vibrissas. Mais uma vez, cada grupo recebeu os implantes em apenas uma destas áreas, a qual foi estimulada eletricamente. No entanto, todos os grupos foram avaliados para a sensibilidade dolorosa em 4 modelos diferentes que avaliam limiar nociceptivo. Sendo cada um para avaliar uma das áreas alvo de estimulação: pata posterior, pata anterior, vibrissas e cauda, escolhidas como se segue: teste de pressão da pata posterior (Randall, Selitto, 1957), teste de limiar de dor mecânica da pata anterior aferida com monofilamentos de von Frey (Takasaki et al., 2001), teste de limiar de dor das vibrissas por von Frey eletrônico (Denadai-Souza, 2009) e teste de pinçamento da cauda (Nalwalk et al., 1995).

Todos os animais foram testados antes do procedimento cirúrgico para que se estabelecessem medidas iniciais de animais de uma mesma população. A segunda etapa iniciou-se com testes nos animais já operados, mas ainda não submetidos à estimulação. Os animais foram então conectados ao estimulador e receberam estimulação em sessões 
de 15 minutos. Ao final deste período, ainda em vigência da estimulação os animais foram submetidos aos mesmos testes. Como grupo controle também foram utilizados animais que não passaram por intervenção cirúrgica (grupo branco), porém foram avaliados nos testes comportamentais nos mesmos parâmetros dos animais implantados.

\subsubsection{Teste de Pressão da Pata}

Este teste foi utilizado conforme descrito por Randall, Selitto (1957). Nele uma força em gramas de intensidade crescente $(16 \mathrm{~g} / \mathrm{s})$ foi continuamente aplicada sobre o dorso de uma das patas posteriores do animal. A resposta nociceptiva do animal foi dada pela reação de "retirada da pata" pressionada. O limiar de dor foi expresso em gramas de força necessária para a indução da reação de retirada. Foram realizadas medidas inicias (antes do procedimento cirúrgico / antes da estimulação cortical) e medidas finais após 15 minutos de estimulação cortical e após o seu término. As duas patas posteriores foram testadas. Os resultados foram expressos através da comparação das médias entre as medidas iniciais e finais.

Figura 2 - Ilustração do teste de pressão da pata

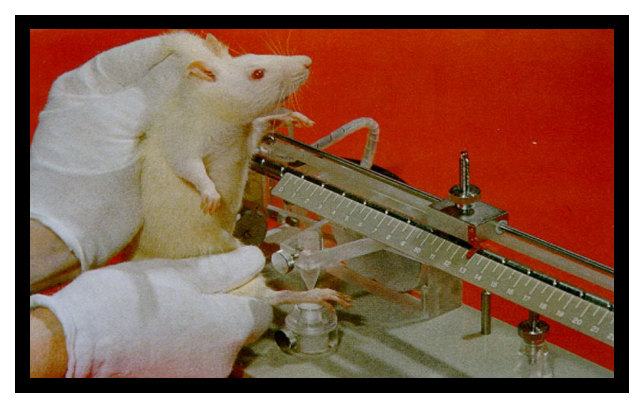

\subsubsection{Hiperalgesia mecânica por filamentos de von Frey}

A hiperalgesia da pata dianteira foi realizada de acordo com o método descrito por Takasaki et al. (2001), modificado. Os ratos foram colocados individualmente em gaiolas plásticas sobre uma plataforma vazada por um período de 30 min. de adaptação. Após este período foram estimulados na superfície subplantar das duas patas dianteiras com monofilamentos de von Frey com as forças de $8 \mathrm{~g}$ (filamento de 4.93), $15 \mathrm{~g}$ e $60 \mathrm{~g}$ (filamentos de 5.18 e 5.88 respectivamente). 
Cada filamento foi pressionado perpendicularmente sob a pata e mantido por $5 \mathrm{~s}$. Uma estimulação de mesma intensidade foi repetida por 3 vezes para cada monofilamento em intervalos de 5s. As respostas aos estímulos foram consideradas da seguinte forma: 0, para ausência de resposta; 1 movimento de retirada da pata do estímulo e 2 balançar e lamber a pata imediatamente após o estímulo. O score nociceptivo foi calculado como se segue:

$$
\text { score nociceptivo }(\%)=\frac{\sum \text { (média do score de cada animal) }}{2 \times \text { n }^{\circ} \text { de animais testados }} \times 100
$$

Figura 3 - Ilustração do teste de estimulação táctil por monofilamentos de von Frey

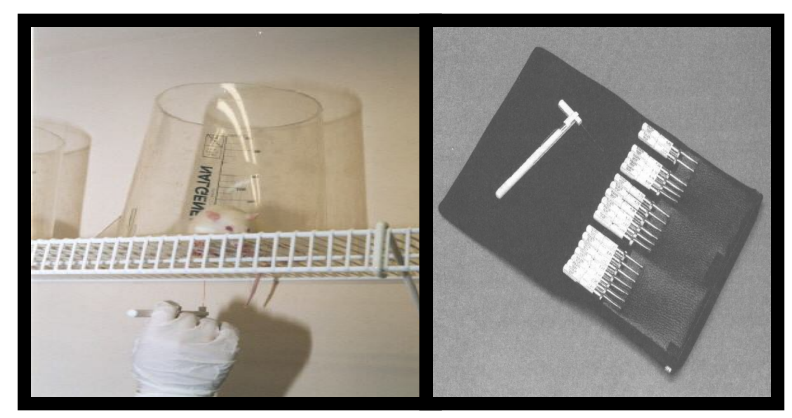

\subsubsection{Teste de pinçamento da cauda}

O teste de pinçamento da cauda foi utilizado de acordo com o método descrito por Nalwalk et al. (1995). Este teste, que avalia o limiar nociceptivo para cauda, consiste na utilização de uma pinça do tipo "jacaré" $(4$ x $0,4 \mathrm{~cm})$ com tubos plásticos ao redor dos dentes que foi utilizada para pinçar a cauda dos ratos, numa região de aproximadamente 2,5 cm a partir da ponta da cauda. A força exercida pela pinça é constante (679 g, determinada com o uso de dinamômetro), ou seja, a pressão sobre a cauda do animal foi constante e o limiar nociceptivo avaliado foi o tempo em segundos que o animal leva para responder ao estímulo seja voltando-se para a pinça na tentativa de retirá-la, seja mordendo-a, vocalizando ou realizando mais de um dos comportamentos citados ao mesmo tempo. Foram realizadas medidas iniciais (antes da estimulação cortical) e finais (após 15 minutos da estimulação). Os resultados foram analisados pela comparação das médias obtidas nos diferentes grupos experimentais. 
Figura 4 - Ilustração da pinça utilizada no teste de pinçamento da cauda

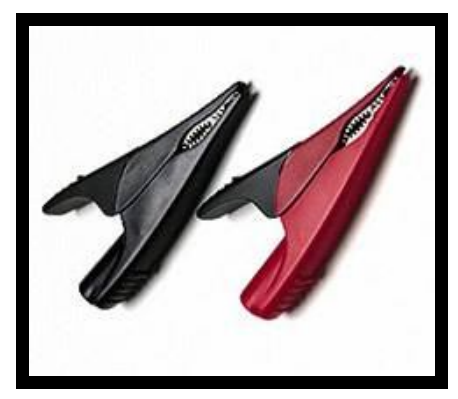

\subsubsection{Alodínia mecânica por von Frey eletrônico}

Esse método foi realizado de acordo com o modelo descrito por Denadai-Souza et al. (2009), modificado. A alodínea mecânica da região das vibrissas foi avaliada medindose o limiar de intensidade de força (em gramas) necessário para ser aplicado na região das vibrissas até a ocorrência de uma resposta de retirada da cabeça do animal. Para tanto, os animais foram colocados individualmente em gaiolas plásticas por um período de 30 min. de adaptação antes da estimulação. Antes do início dos experimentos os animais foram submetidos a sessões de condicionamento nos dois dias anteriores ao experimento. As medidas dos limiares de força foram realizadas em triplicatas. Realizaram-se medidas antes e após os 15 minutos da seção de estimulação. Os resultados foram analisados pela comparação das médias obtidas nos diferentes grupos experimentais.

Figura 5 - Ilustração do teste de alodínia mecânica por von Frey eletrônico

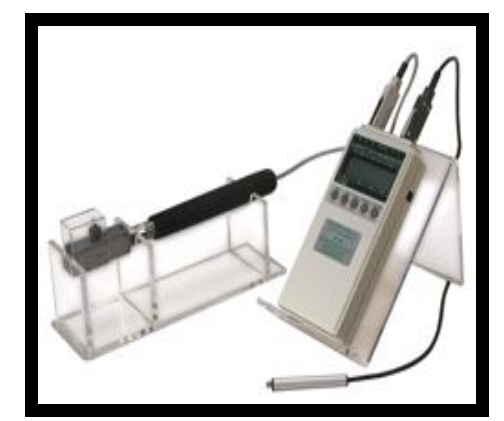




\subsection{Imuno-histoquímica}

A imuno-histoquímica foi efetuada segundo o método descrito por Castex et al. (1995). Ratos não implantados (Grupo Branco) e implantados, estimulados eletricamente ou não (Grupos Estimulado e Não Estimulado), foram anestesiados profundamente com uma associação de Ketamina e Xilazina (500 $\mu \mathrm{L}$ v:v/animal, i.p.) sendo, então, realizada perfusão sistêmica através de uma cânula introduzida no ventrículo esquerdo com 300 a $400 \mathrm{~mL}$ de salina tamponada (PBS 0,1 M) e em seguida com $300 \mathrm{~mL}$ de fixador (paraformaldeído 4\% em PB) 0,1 M). Imediatamente após, foi feita a retirada do encéfalo e medula espinhal os quais permaneceram no mesmo fixador por no mínimo 4 horas sendo estas estruturas, em seguida, "crioprotegidas" por 24 horas em solução de sacarose a $30 \%$ em PB. Os tecidos foram cortados por congelação em micrótomo $(30 \mu \mathrm{m})$ e os cortes coletados em PB. A seguir, os cortes foram lavados em PB 0,1M (3 vezes por 10 minutos) e incubados overnight com anticorpos monoclonais específicos para c-Fos (Calbiochem) e egr-1 (Santa Cruz Biotechnology), diluídos 1:1000. Antes da incubação por 2 horas com o anticorpo secundário biotinilado (diluição de 1:200), os cortes foram novamente lavados (3 vezes por 10 minutos). À incubação com o anticorpo secundário (Jackson), seguiu a incubação com avidina (1:100) e biotina (1:100) por 2 horas. Em seguida, foi realizada a revelação com peróxido de hidrogênio $\left(\mathrm{H}_{2} \mathrm{O}_{2}\right)$ utilizando-se diaminobenzidina (DAB) como cromógeno. Os cortes histológicos foram montados sobre lâminas de vidro gelatinizadas as quais foram submetidas à desidratação em temperatura ambiente, foram protegidas com meio de montagem à base de glicerol e cobertas com lamínulas. A imunorreatividade foi analisada ao microscópio de luz com as imagens retiradas utilizando-se o programa NIS Elements F3.0 e as quantificações foram realizadas com o programa Image $\mathbf{J}$, a partir da seleção aleatória de 5 a 9 cortes por animal de cada grupo. A CPME foi dividida em lâminas superficiais (LS), que consideram as lâminas I à IV e em lâminas profundas (LP), segundo a classificação de Rexed (Todd, 2010). A PAG foi analisada em 6 níveis de secção arranjadas no sentido rostral para o caudal, esses níveis foram nomeados A, B, C, D, E e F, e cada qual contém dentro de si as divisões em colunas desta estrutura (dorsomedial, dorsolateral, lateral e ventrolateral) (Comoli et 
al., 2003; Ruiz-Torner, 2001). Para cada animal de cada grupo procurou-se analisar em torno de 2 a 3 cortes de cada nível.

\subsection{Análise estatística}

Os resultados obtidos foram expressos como média \pm erro padrão da média (e.p.m) e analisados estatisticamente por Análise de Variância de 1 via (ANOVA). O teste de Tukey foi utilizado para detectar as diferenças das médias após a Análise de Variância para medidas não repetidas (Snedecor, 1956; Snedecor, Cochran, 1974). O índice de significância considerado foi de $\mathrm{p}<0,05$. Os cálculos foram efetuados utilizando-se o software GraphPad Prism version 5 (GraphPad Software Inc., CA, USA). 


\section{RESULTADOS}

\subsection{Efeito da ECM sobre a Somatotopia do córtex motor}

Todos os grupos experimentais receberam implante no córtex motor em região específica de acordo com as áreas do estudo e após 7 dias da cirurgia foram submetidos a uma sessão de estimulação elétrica de 15 min de duração e após este período, ainda sob estimulação, foram avaliados em quatro testes nociceptivos comportamentais: teste de von Frey eletrônico para estimulação da área das vibrissas; filamentos de von Frey para estimulação da pata anterior; teste de pinçamento da cauda e teste de pressão da pata posterior.

Os resultados obtidos nos testes comportamentais demonstraram que o efeito antinociceptivo induzido pela ECM possui relação topográfica entre a área do córtex motor avaliada e o membro avaliado. Dessa forma, observamos que no grupo de animais que recebeu implante na área correspondente às vibrissas a ECM induziu analgesia nos animais avaliados por von Frey eletrônico (Fig. 6A), sem interferir com o limiar nociceptivo avaliado nos outros testes comportamentais (Fig. 6). Nos ratos implantados na região de Pata Anterior o teste que apresentou alteração no limiar nociceptivo demonstrando analgesia foi o teste de limiar táctil aferido por monofilamentos de von Frey (Fig. 7B). O teste de pinçamento da cauda demonstrou uma indução de analgesia frente a ECM para a cauda nos animais com implante na região do córtex motor correspondente à essa estrutura (Fig. 8C) e apresentaram analgesia no teste de pressão da pata o grupo de animais implantados na região do córtex motor correspondente à pata posterior (Fig. 9D). O efeito antinociceptivo foi observado apenas no membro correspondente à área do córtex motor estimulada, não sendo observada nenhuma alteração significante do limiar nociceptivo nos demais testes comportamentais avaliados, para cada grupo experimental. 
Figura 6 - Efeito da ECM, na área correspondente às vibrissas, sobre o limiar nociceptivo de ratos

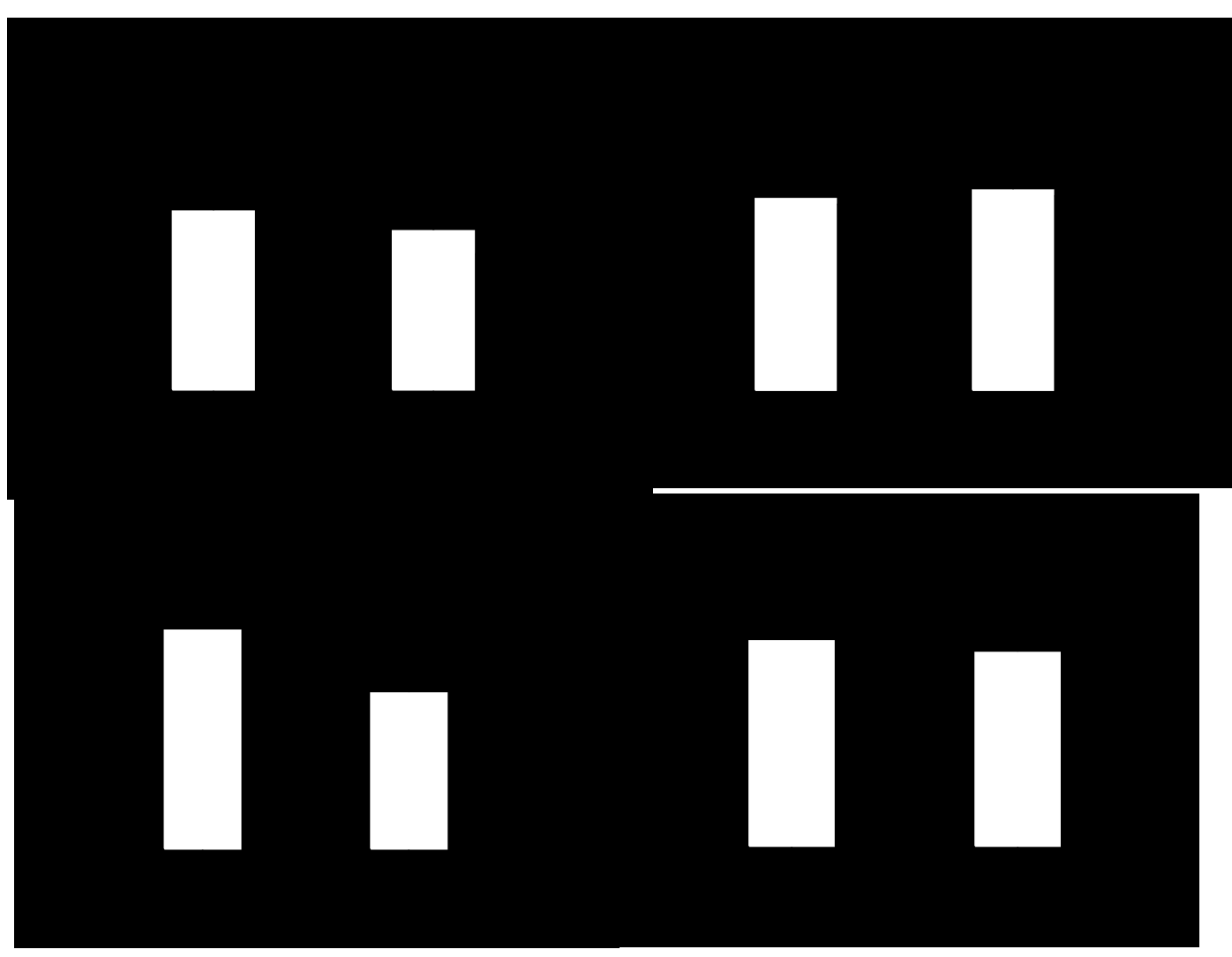

Efeito da estimulação elétrica transdural do córtex motor, na área correspondente às vibrissas, sobre o limiar nociceptivo de ratos. A: estimulação táctil das vibrissas. B: estimulação táctil por monofilamentos de von Frey da pata anterior. C: teste de pinçamento da cauda. D: teste de pressão de pata para a pata posterior. Os testes nociceptivos foram aplicados antes (MI) e 15 min. após a sessão de estimulação (15-min.). O grupo estimulado corresponde aos animais implantados e avaliados nestes modelos sob estimulação elétrica. O grupo não estimulado corresponde aos animais implantados na mesma área, mas não estimulados (grupo controle). Os dados representam a média \pm e.p.m. de 5-6 animais por grupo. ${ }^{*} \mathrm{p}<0,05$ em relação ao grupo controle. 
Figura 7 - Efeito da ECM, na área correspondente à pata anterior sobre o limiar nociceptivo de ratos

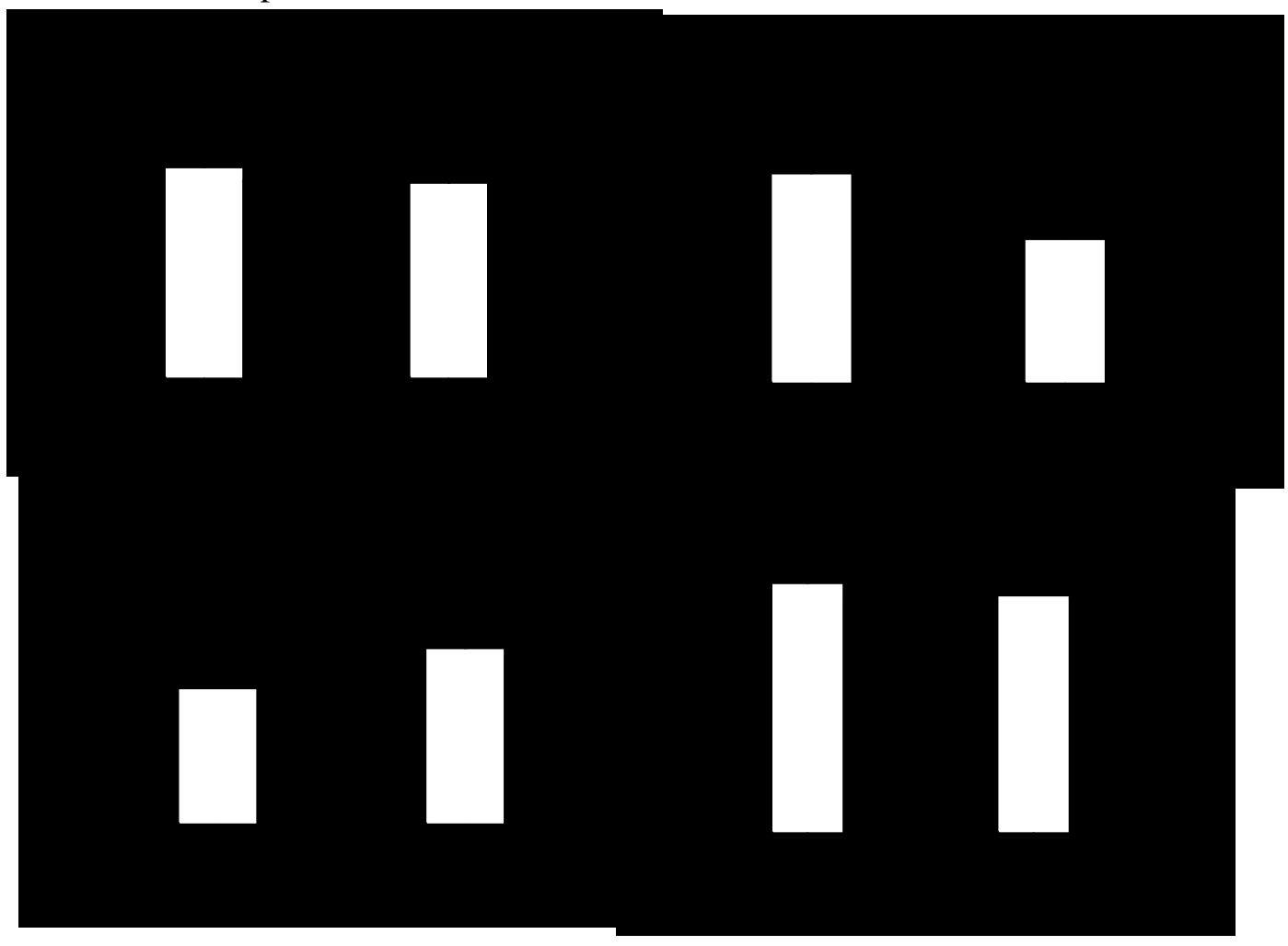

Efeito da estimulação elétrica transdural do córtex motor, na área correspondente à pata anterior, sobre o limiar nociceptivo de ratos. A: estimulação táctil das vibrissas. B: Estimulação táctil por monofilamentos de von Frey da pata anterior. C: teste de pinçamento da cauda. D: teste de pressão de pata para a pata posterior. Os testes nociceptivos foram aplicados antes (MI) e 15 min. após a sessão de estimulação (15-min.). O grupo estimulado corresponde aos animais implantados e avaliados nestes modelos, sob estimulação elétrica. $O$ grupo não estimulado corresponde aos animais implantados na mesma área, mas não estimulados (grupo controle). Os dados representam a média \pm e.p.m. de 5-6 animais por grupo. ${ }^{*}$ p $<0,01$ em relação ao grupo controle. 
Figura 8 - Efeito da ECM, na área correspondente à cauda, sobre o limiar nociceptivo de ratos

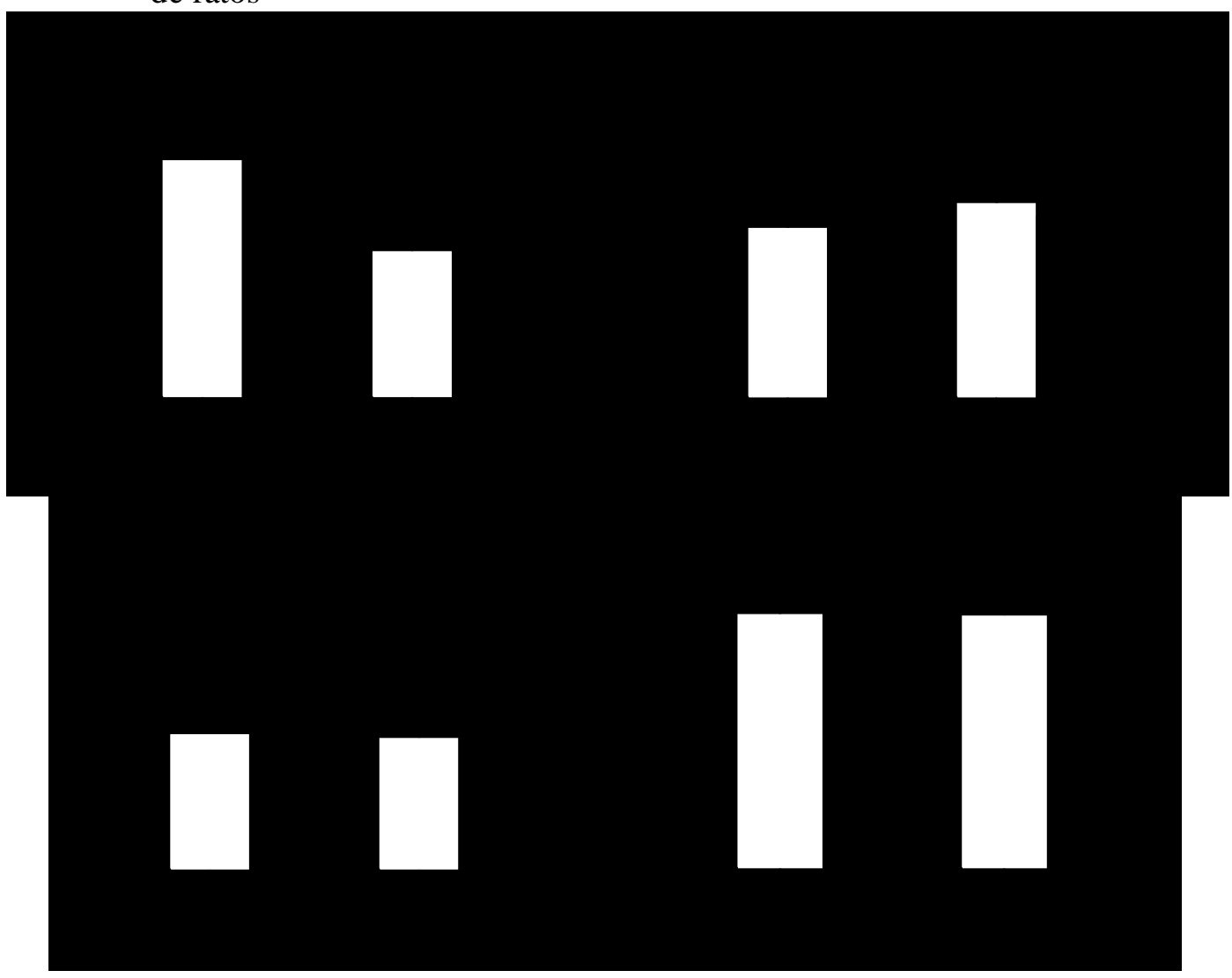

Efeito da estimulação elétrica transdural do córtex motor, na área correspondente à cauda, sobre o limiar nociceptivo de ratos. A: estimulação táctil das vibrissas. B: estimulação táctil por monofilamentos de von Frey da pata anterior. C: teste de pinçamento da cauda. D: teste de pressão de pata para a pata posterior. Os testes nociceptivos foram aplicados antes (MI) e 15 min. após a sessão de estimulação (15-min.). O grupo estimulado corresponde aos animais implantados e avaliados nestes modelos, sob estimulação elétrica. $\mathrm{O}$ grupo não estimulado corresponde aos animais implantados na mesma área, mas não estimulados (grupo controle). Os dados representam a média \pm e.p.m. de 5-6 animais por grupo. ${ }^{*} \mathrm{p}<0,01$ em relação ao grupo controle. 
Figura 9 - Efeito da ECM, na área correspondente à pata posterior sobre o limiar nociceptivo de ratos

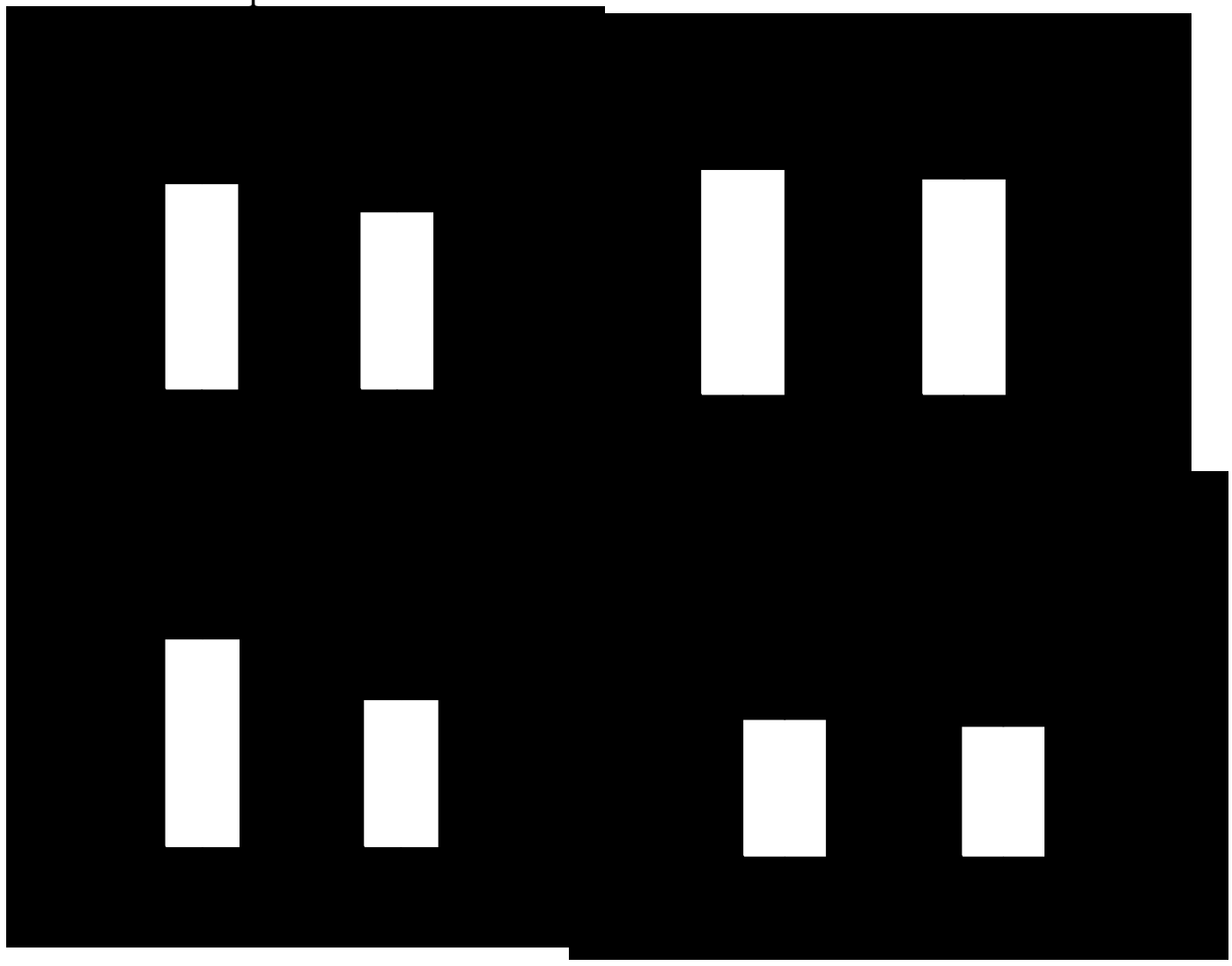

Efeito da estimulação elétrica transdural do córtex motor, na área correspondente à pata posterior, sobre o limiar nociceptivo de ratos. A: estimulação táctil das vibrissas. B: estimulação táctil por monofilamentos de von Frey da pata anterior. C: teste de pinçamento da cauda. D: teste de pressão de pata para a pata posterior. Os testes nociceptivos foram aplicados antes (MI) e 15 min. após a sessão de estimulação (15-min.). O grupo estimulado corresponde aos animais implantados e avaliados nestes modelos, sob estimulação elétrica. $\mathrm{O}$ grupo não estimulado corresponde aos animais implantados na mesma área, mas não estimulados (grupo controle). Os dados representam a média \pm e.p.m. de 5-6 animais por grupo. ${ }^{* * *} \mathrm{p}<0,001$ em relação ao grupo controle. 


\subsection{Efeito da ECM sobre a ativação neuronal de áreas envolvidas na transmissão} nociceptiva

\subsubsection{Efeito da ECM sobre a ativação neuronal na CPME}

A ECM foi capaz de induzir uma diminuição significativa da expressão da proteína Fos na CPME dos animais estimulados nas diferentes áreas do córtex motor (Fig 10), sendo este efeito observado nas lâminas superficiais para cada grupo experimental avaliado (Figs. 11, 12). Com relação à proteína Egr-1, os dados obtidos demonstraram uma tendência à diminuição para a imunomarcação, mas a análise dos resultados não demonstrou diferenças significativas entre os grupos (Fig. 13). No entanto, quando foi realizada a quantificação para as diferentes lâminas, observou-se uma diminuição significativa da imunoreatividade para a proteína Egr-1 entre os grupos avaliados nas lâminas superficiais da CPME (Figs. 14 e15), 
Figura 10 - Quantificação da marcação neuronal pela expressão de Fos na medula espinal
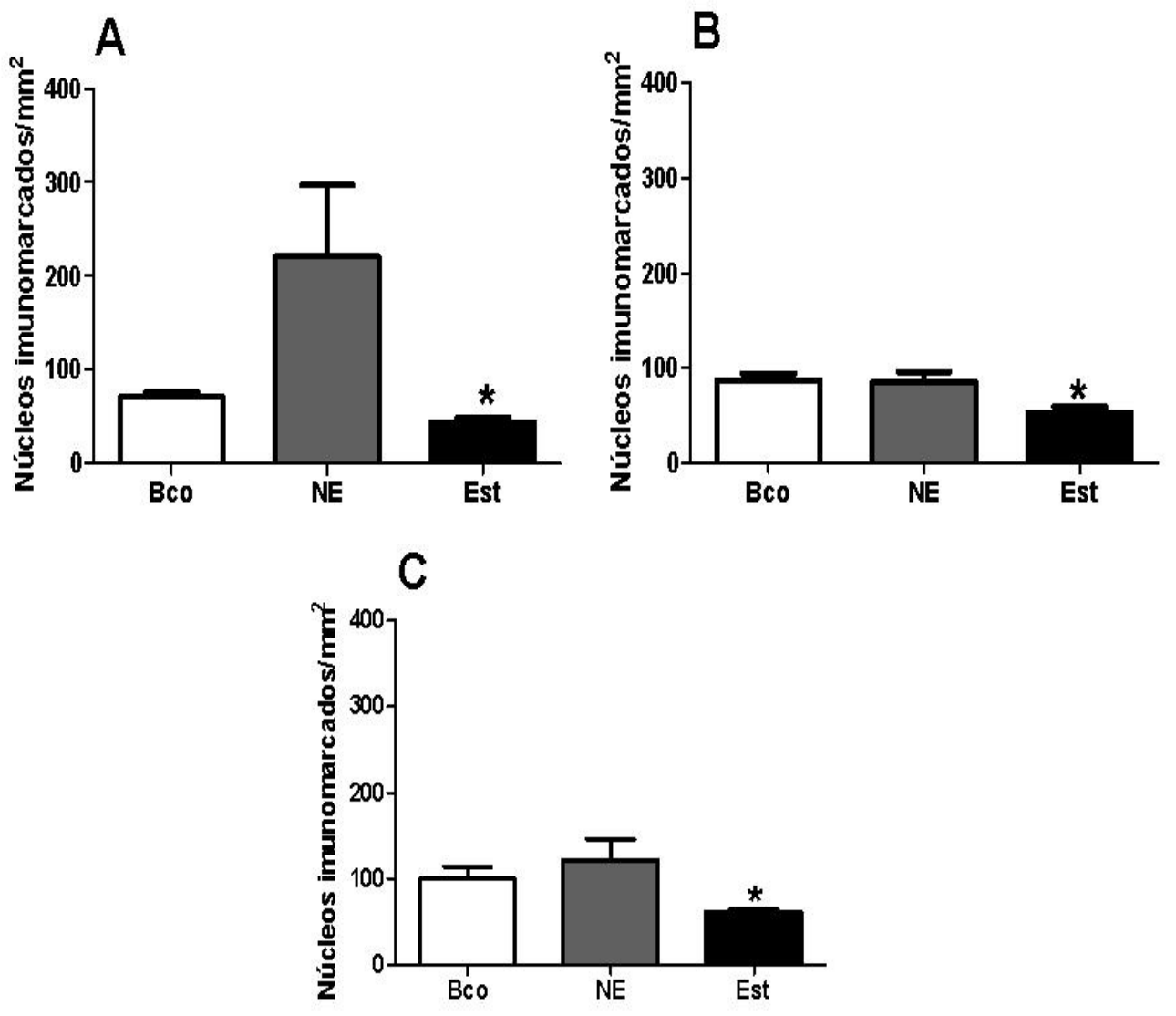

Quantificação da marcação neuronal pela expressão de Fos na medula espinal de animais implantados na região do córtex motor nas áreas correspondentes a: (A) pata posterior, (B) pata anterior e $(\mathrm{C})$ cauda. O grupo branco (Bco) corresponde aos animais sem intervenção cirúrgica. $\mathrm{O}$ grupo não estimulado (NE) corresponde aos animais implantados, mas não estimulados (grupo controle) e o grupo estimulado (Est) corresponde aos animais implantados e estimulados eletricamente. Os dados representam a média \pm e.p.m. de 3-5 animais por grupo.* $\mathrm{p}<0,05 \mathrm{em}$ relação ao grupo NE. 
Figura 11 - Quantificação da marcação neuronal pela expressão de Fos nas Lâminas superficiais (I-IV) e profundas (V e VI) da CPME

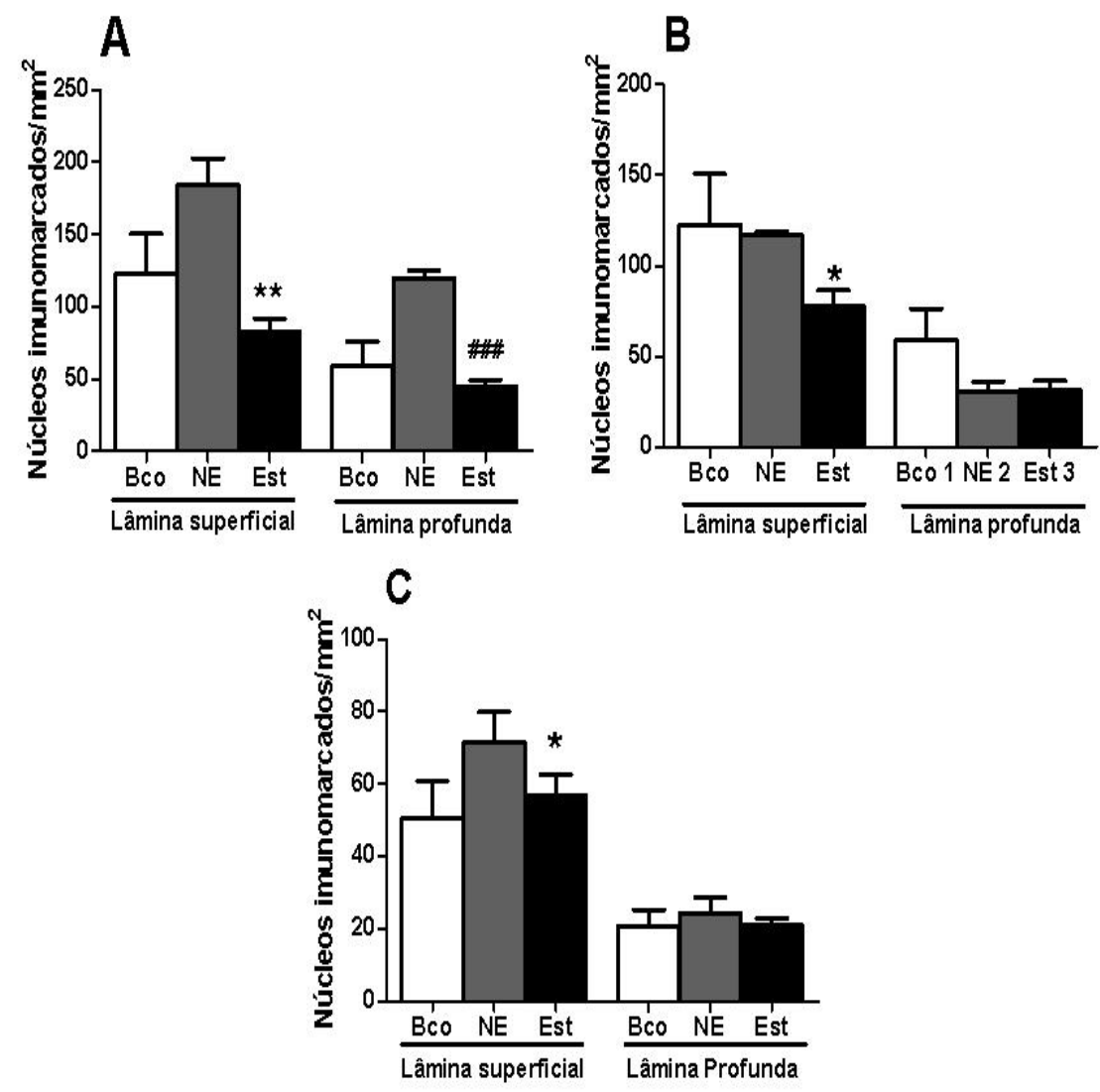

Quantificação da marcação neuronal pela expressão de Fos nas Lâminas superficiais (I-IV) e profundas (V e VI) da CPME de animais implantados na região do córtex motor nas áreas correspondentes à: (A) pata posterior, (B) pata anterior ou (C) cauda. O grupo branco (Bco) corresponde aos animais sem intervenção cirúrgica. $\mathrm{O}$ grupo não estimulado (NE) corresponde aos animais implantados, mas não estimulados (grupo controle) e o grupo estimulado (Est) corresponde aos animais implantados e estimulados eletricamente. Os dados representam a média \pm e.p.m. de 3-5 animais por grupo.* $\mathrm{p}<0,05 * * \mathrm{p}<0,001$ em relação ao grupo NE. 
Figura 12 - Fotomicrografia representativa de secções da coluna posterior da medula espinal (lado direito) submetidas à imunohistoquímica para Fos
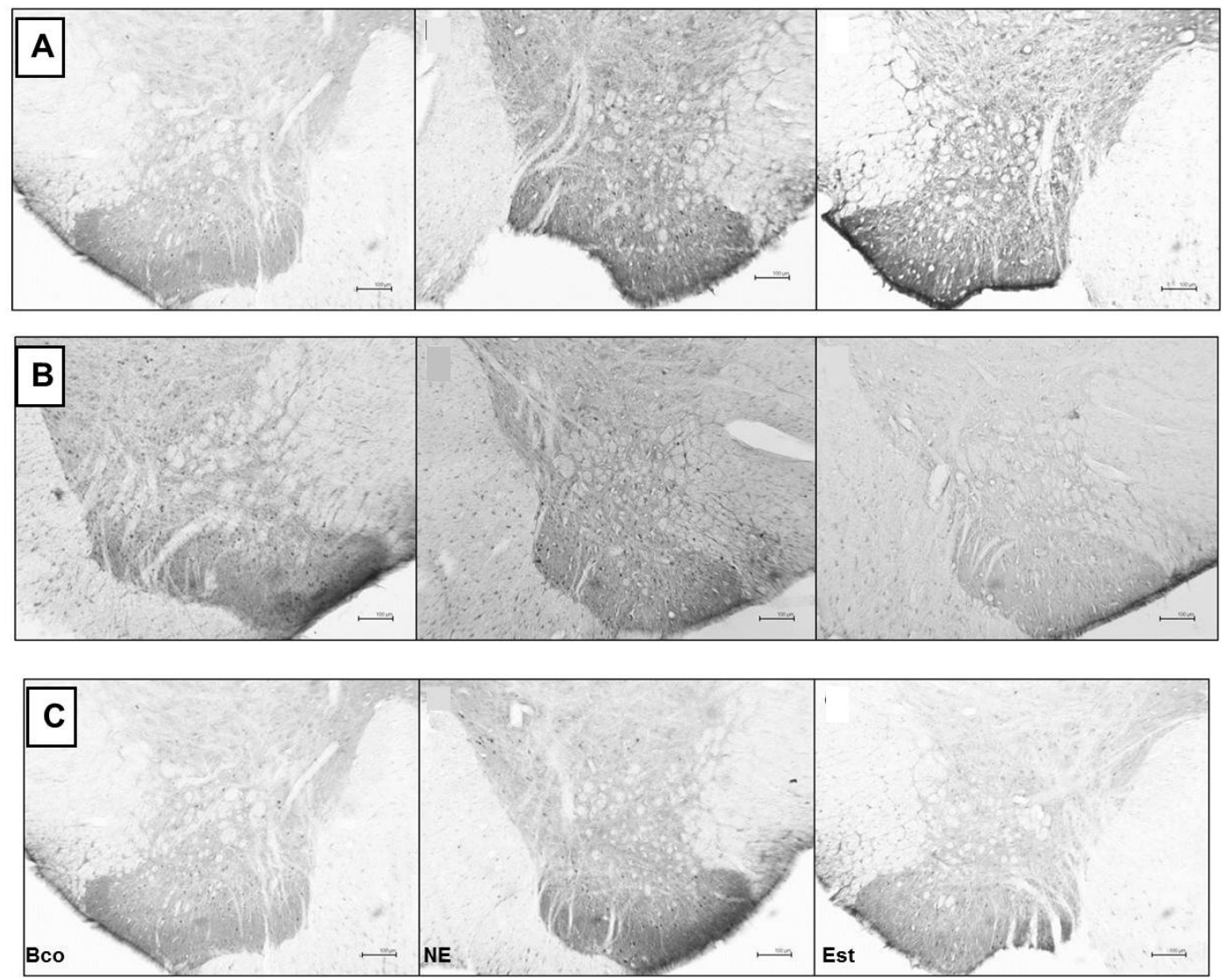

Fotomicrografia representativa de secções da coluna posterior da medula espinal (lado direito) submetidas à imunohistoquímica para Fos de animais implantados na região do córtex motor nas áreas correspondentes à: (A) pata posterior, (B) pata anterior ou (C) cauda. Os eletrodos corticais foram implantados no hemisfério esquerdo. Bco: cortes obtidos de animais sem intervenção cirúrgica. NE: cortes obtidos de animais implantados na mesma área, mas não estimulados. Est: cortes obtidos de animais implantados e estimulados eletricamente. Escala (-) $=100 \mu \mathrm{m}$. 
Figura 13 - Quantificação da marcação neuronal pela expressão de Egr-1 na medula espinal

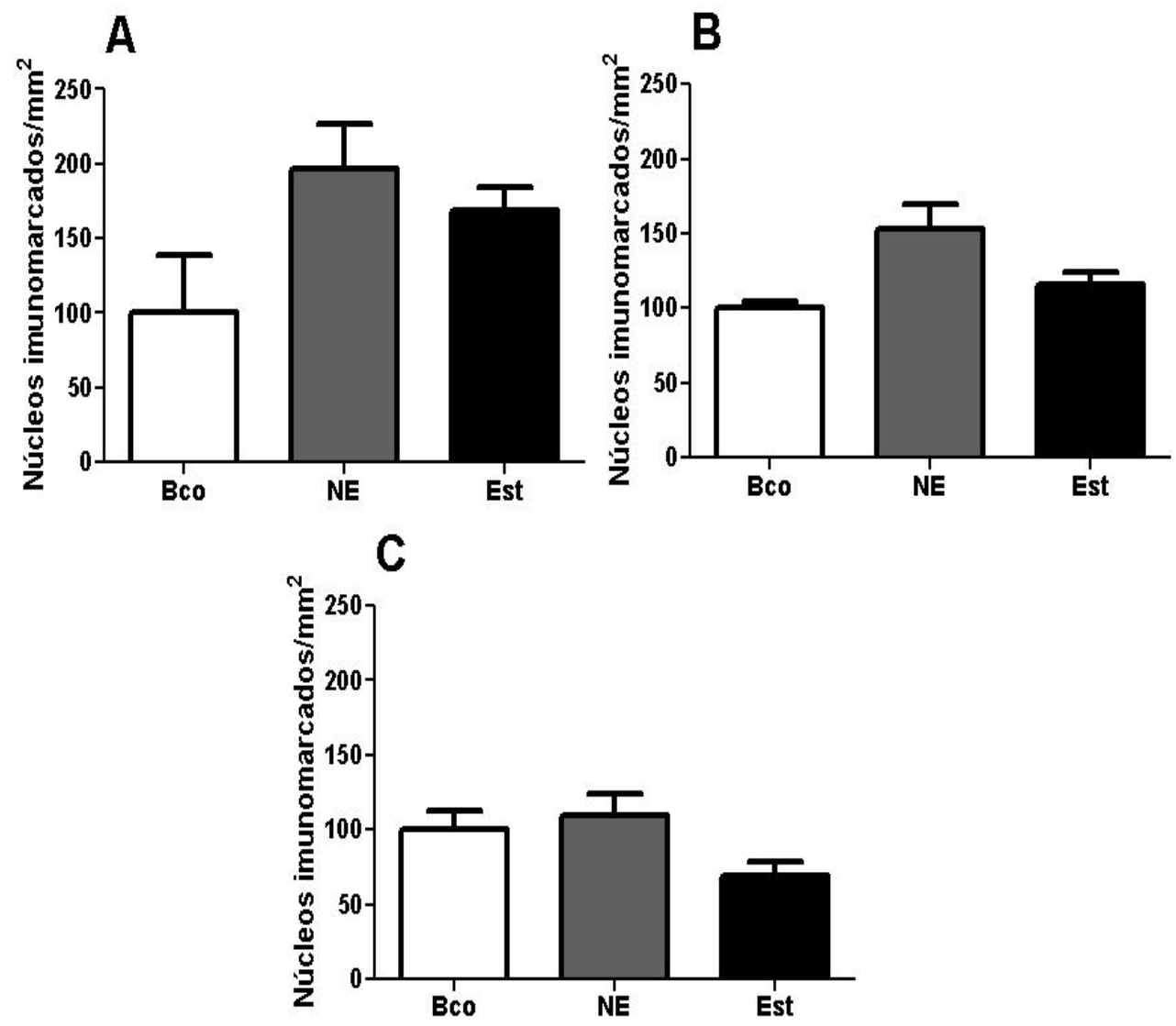

Quantificação da marcação neuronal pela expressão de Egr-1 na medula espinal de animais implantados na região do córtex motor nas áreas correspondentes a: (A) pata posterior, (B) pata anterior e $(\mathrm{C})$ cauda. O grupo branco (Bco) corresponde aos animais sem intervenção cirúrgica. $\mathrm{O}$ grupo não estimulado (NE) corresponde aos animais implantados, mas não estimulados (grupo controle) e o grupo estimulado (Est) corresponde aos animais implantados e estimulados eletricamente. Os dados representam a média \pm e.p.m. de 3-5 animais por grupo. 
Figura 14 - Quantificação da marcação neuronal pela expressão de Egr-1 nas Lâminas superficiais (I-IV) e profundas (V e VI) da CPME

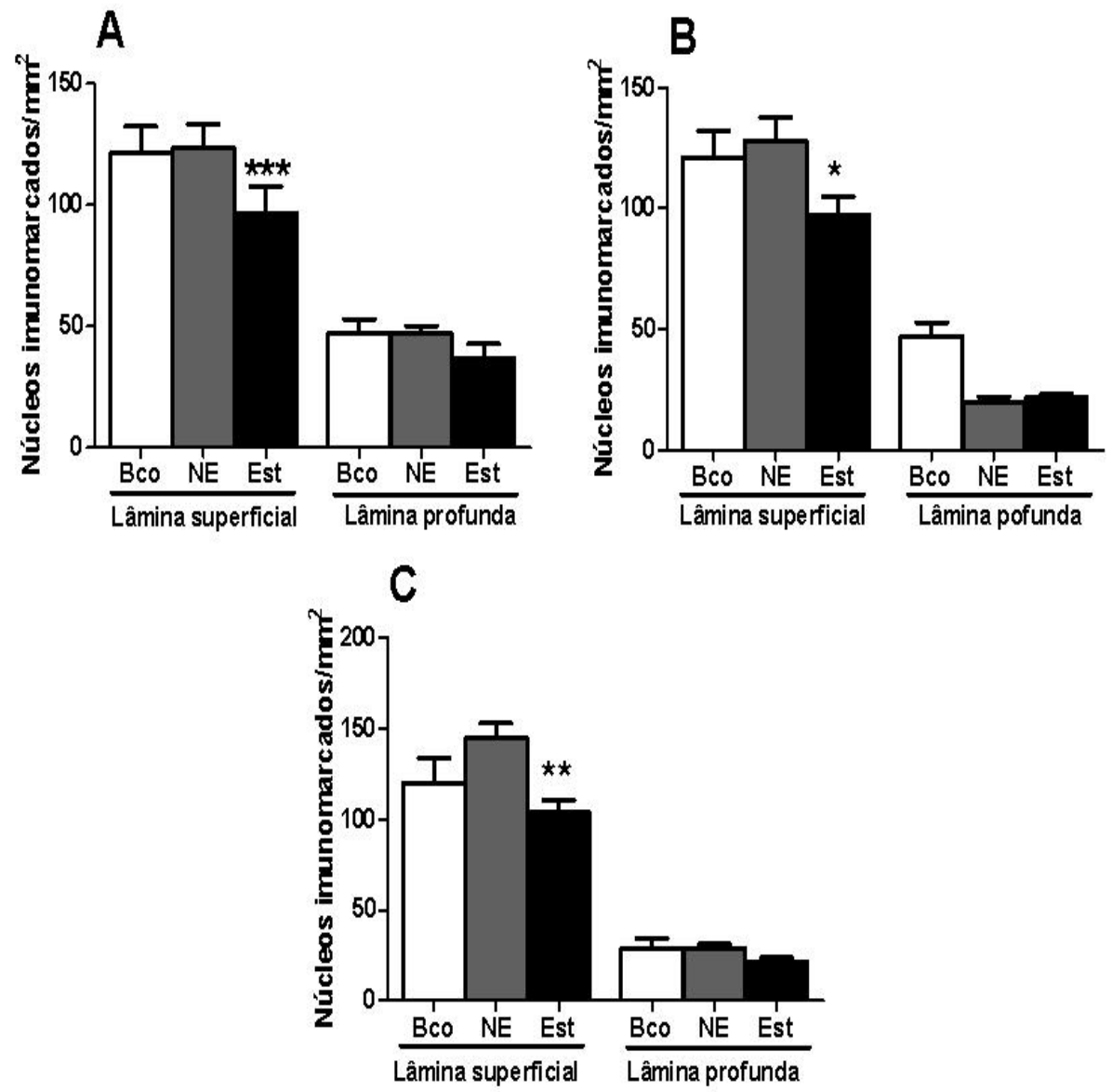

Quantificação da marcação neuronal pela expressão de Egr-1 nas Lâminas superficiais (I-IV) e profundas (V e VI) da CPME de animais implantados na região do córtex motor nas áreas correspondentes à: (A) pata posterior, $(\mathrm{B})$ pata anterior ou $(\mathrm{C})$ cauda. $\mathrm{O}$ grupo branco $(\mathrm{Bco})$ corresponde aos animais sem intervenção cirúrgica. O grupo não estimulado (NE) corresponde aos animais implantados, mas não estimulados (grupo controle) e o grupo estimulado (Est) corresponde aos animais implantados e estimulados eletricamente. Os dados representam a média \pm e.p.m. de 3-5 animais por grupo. ${ }^{*} \mathrm{p}<0,05 * * \mathrm{p}<0,001 * * * \mathrm{p}<0,001$ em relação ao grupo NE. 
Figura 15 - Fotomicrografia representativa de secções da coluna posterior da medula espinal (lado direito) submetidas à imunohistoquímica para Egr-1
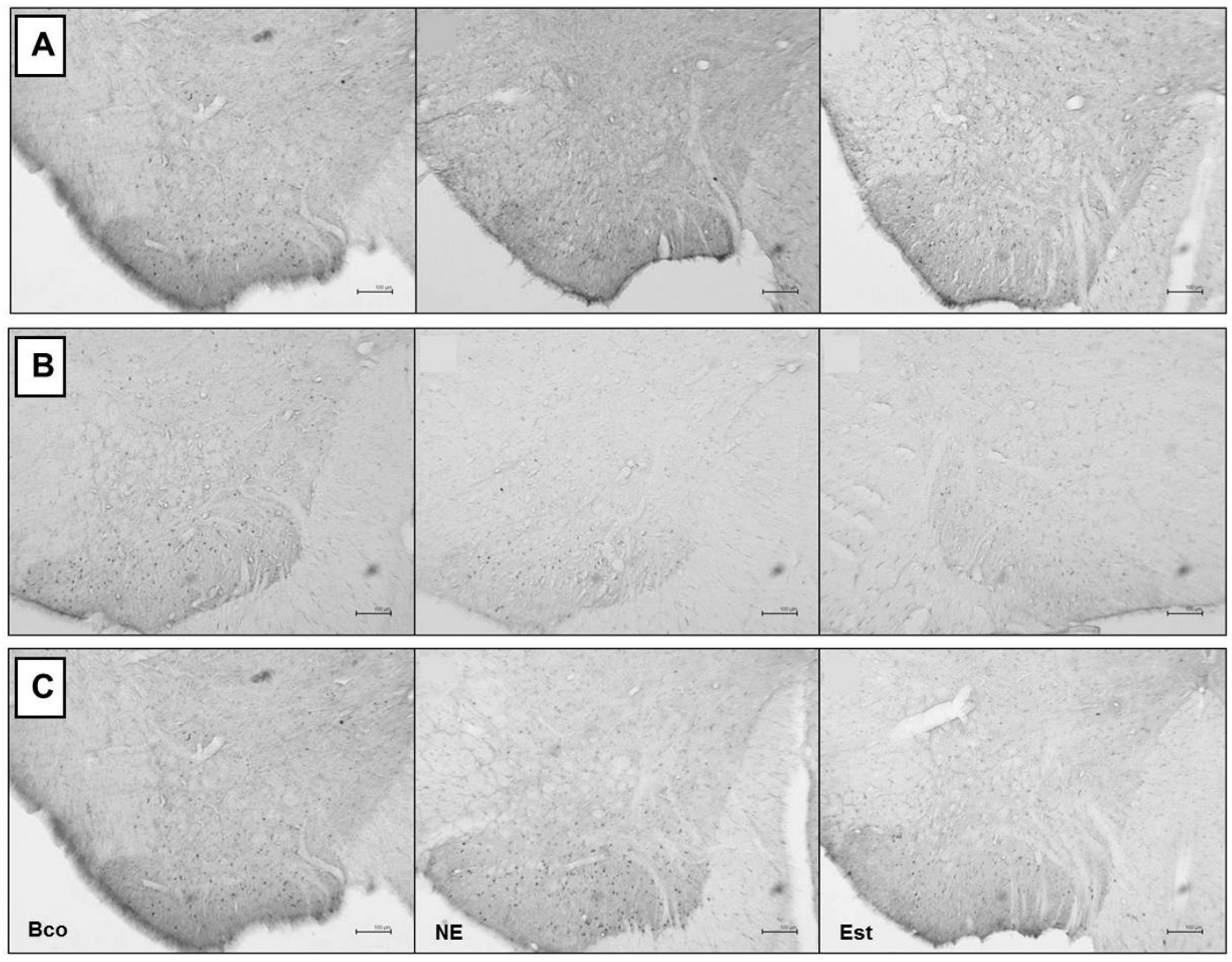

Fotomicrografia representativa de secções da coluna posterior da medula espinal (lado direito) submetidas à imunohistoquímica para Egr-1 de animais implantados na região do córtex motor nas áreas correspondentes à: (A) pata posterior, (B) pata anterior ou (C) cauda. Os eletrodos corticais foram implantados no hemisfério esquerdo. Bco: cortes obtidos de animais sem intervenção cirúrgica. NE: cortes obtidos de animais implantados na mesma área, mas não estimulados. Est: cortes obtidos de animais implantados e estimulados eletricamente. Escala (-) $=100 \mu \mathrm{m}$. 


\subsubsection{Efeito da ECM sobre a ativação neuronal na PAG}

Os resultados obtidos demonstraram uma tendência ao aumento da expressão de Fos na região da PAG (Fig. 16). Este aumento foi significativo apenas no grupo de animais estimulados na área correspondente à pata posterior (Fig. 16 A), no entanto nos três grupos de estimulação foi observado aumento na expressão de Fos. Uma análise mais detalhada da região da PAG, seguindo-se uma divisão em 6 níveis de secção demonstrou que este aumento de expressão de Fos foi significante no nível E para os grupos implantados na região da pata posterior e pata anterior (Figs. 17, 18, 19 e 20). Nesses grupos, além do aumento da expressão de Fos no nível E, observou-se também uma inibição deste protooncogene no nível B (Figs. 17, 18, 19 e 20). Nenhuma alteração significativa foi observada no grupo de animais que receberam implante no córtex motor na região correspondente à cauda (Fig. 21). Resultados semelhantes foram observados quanto à expressão de Egr-1 sendo que foi observado aumento na expressão desta proteína apenas no nível E dos grupos de animais implantados nas áreas da pata posterior e anterior (Figs.23, 24, 25 e 26) sendo que nenhuma alteração foi observada no grupo que recebeu implante na área da cauda (Fig. 27). 
Figura 16 - Quantificação da marcação neuronal pela expressão de Fos na PAG

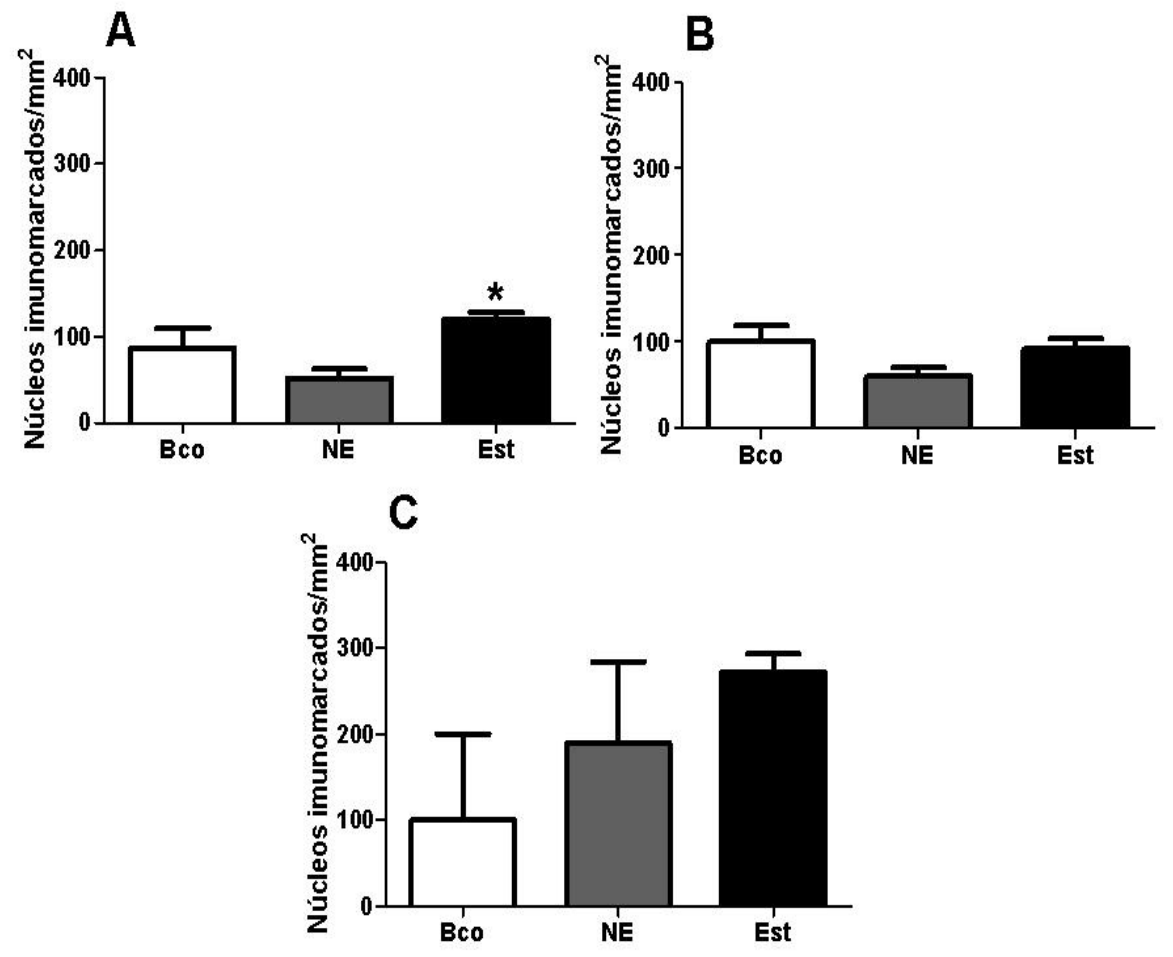

Quantificação da marcação neuronal pela expressão de Fos na PAG de animais implantados na região do córtex motor nas áreas correspondentes a: (A) pata posterior, (B) pata anterior e (C) cauda. O grupo branco (Bco) corresponde aos animais sem intervenção cirúrgica. $\mathrm{O}$ grupo não estimulado (NE) corresponde aos animais implantados, mas não estimulados (grupo controle) e o grupo estimulado (Est) corresponde aos animais implantados e estimulados eletricamente. Os dados representam a média \pm e.p.m. de 3-5 animais por grupo. .* $\mathrm{p}<0,05$ em relação ao grupo NE. 
Figura 17 - Quantificação da marcação neuronal pela expressão de Fos na PAG de animais implantados na região do córtex motor correspondente à Pata Posterior

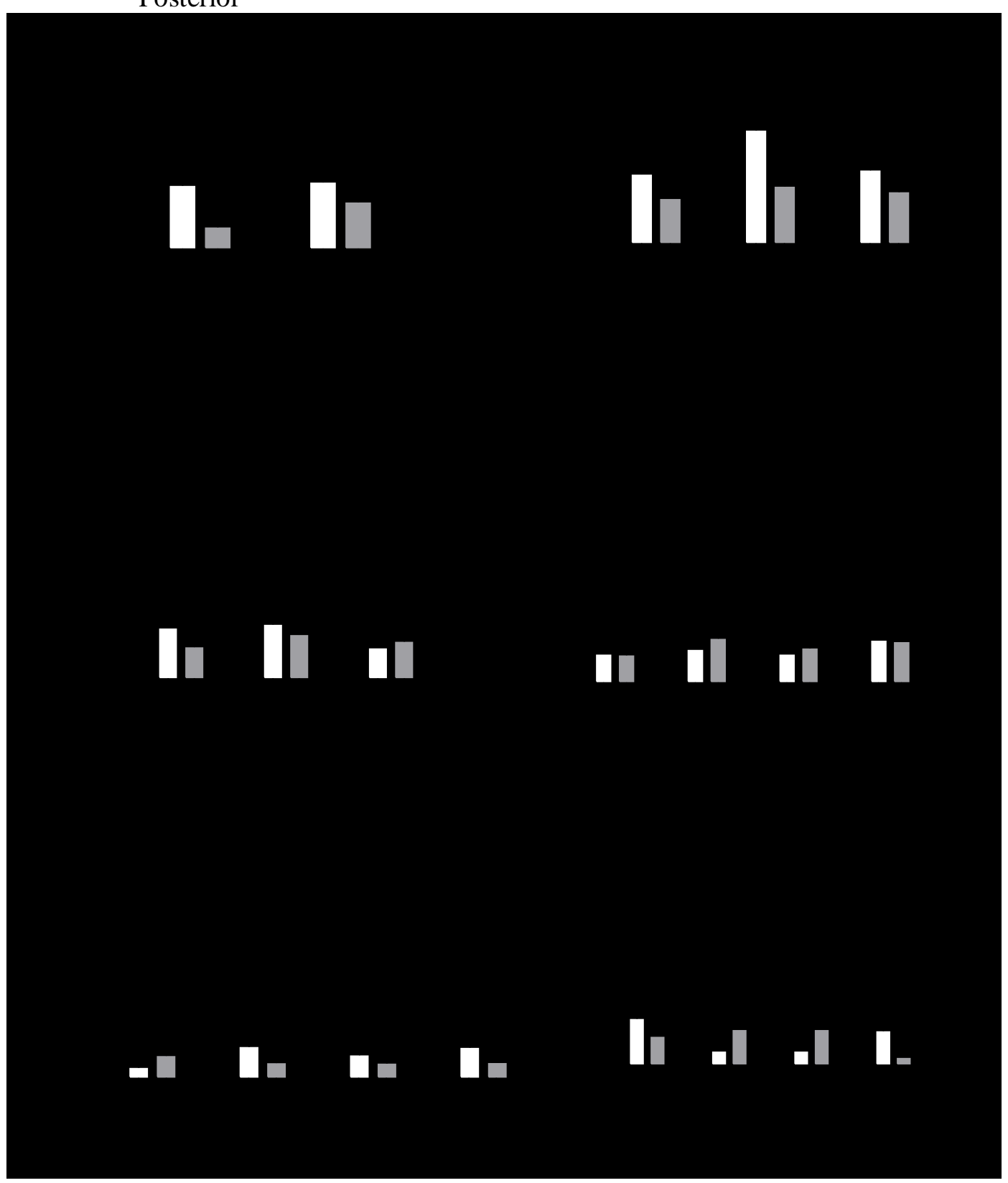

Quantificação da marcação neuronal pela expressão de Fos na PAG de animais implantados na região do córtex motor correspondente à Pata Posterior. A área representada é a PAG divida em níveis A, B, C, D, E e F (sentido rostral-caudal). O grupo estimulado (Est) corresponde aos animais estimulados elétricamente. $\mathrm{O}$ grupo não estimulado $(\mathrm{Ne})$ corresponde aos animais implantados na mesma área, mas não estimulados. O grupo branco (Bco) corresponde aos animais sem intervenção cirúrgica (grupo controle). Os dados representam a média \pm e.p.m. de 2-5 animais por grupo.

$* \mathrm{p}<0,05 * * \mathrm{p}<0,001 * * * \mathrm{p}<0,0001$ em relação ao grupo Ne. 
Figura 18 - Fotomicrografia de secções da PAG submetidas à imunohistoquímica para Fos de ratos implantados na região do córtex motor correspondente à Pata Posterior

\section{Nível B}

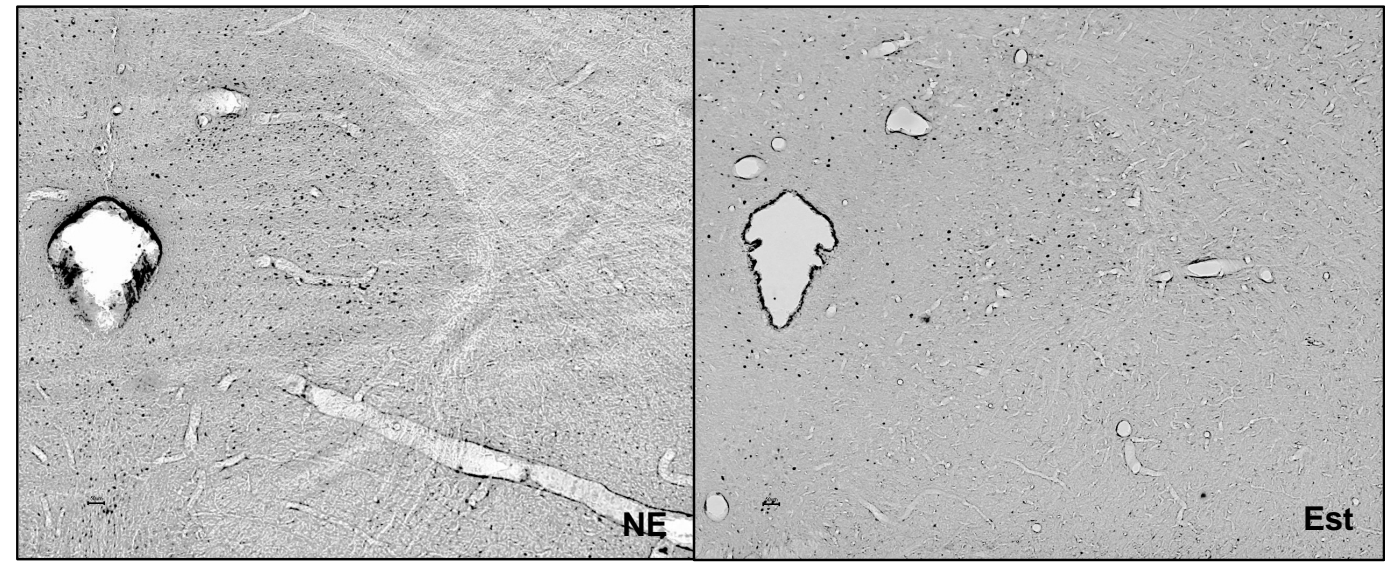

Nível E

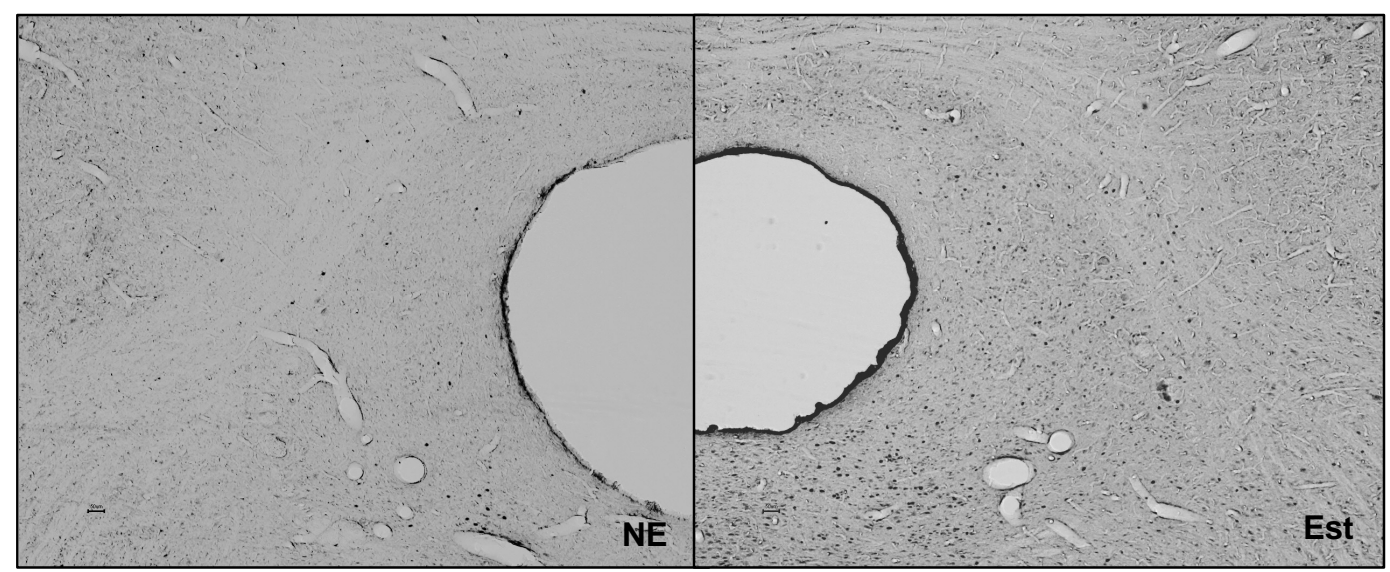

Fotomicrografia de secções da PAG submetidas à imunohistoquímica para Fos de ratos implantados na região do córtex motor correspondente à Pata Posterior com alterações significativas no padrão de expressão. Os eletrodos corticais foram implantados no hemisfério esquerdo. NE: cortes obtidos de animais implantados na mesma área, mas não estimulados. Est: cortes obtidos de animais implantados e estimulados eletricamente. Escala $(-)=50 \mu \mathrm{m}$. 
Figura 19 - Quantificação da marcação neuronal pela expressão de Fos na PAG de animais implantados na região do córtex motor correspondente à Pata Anterior

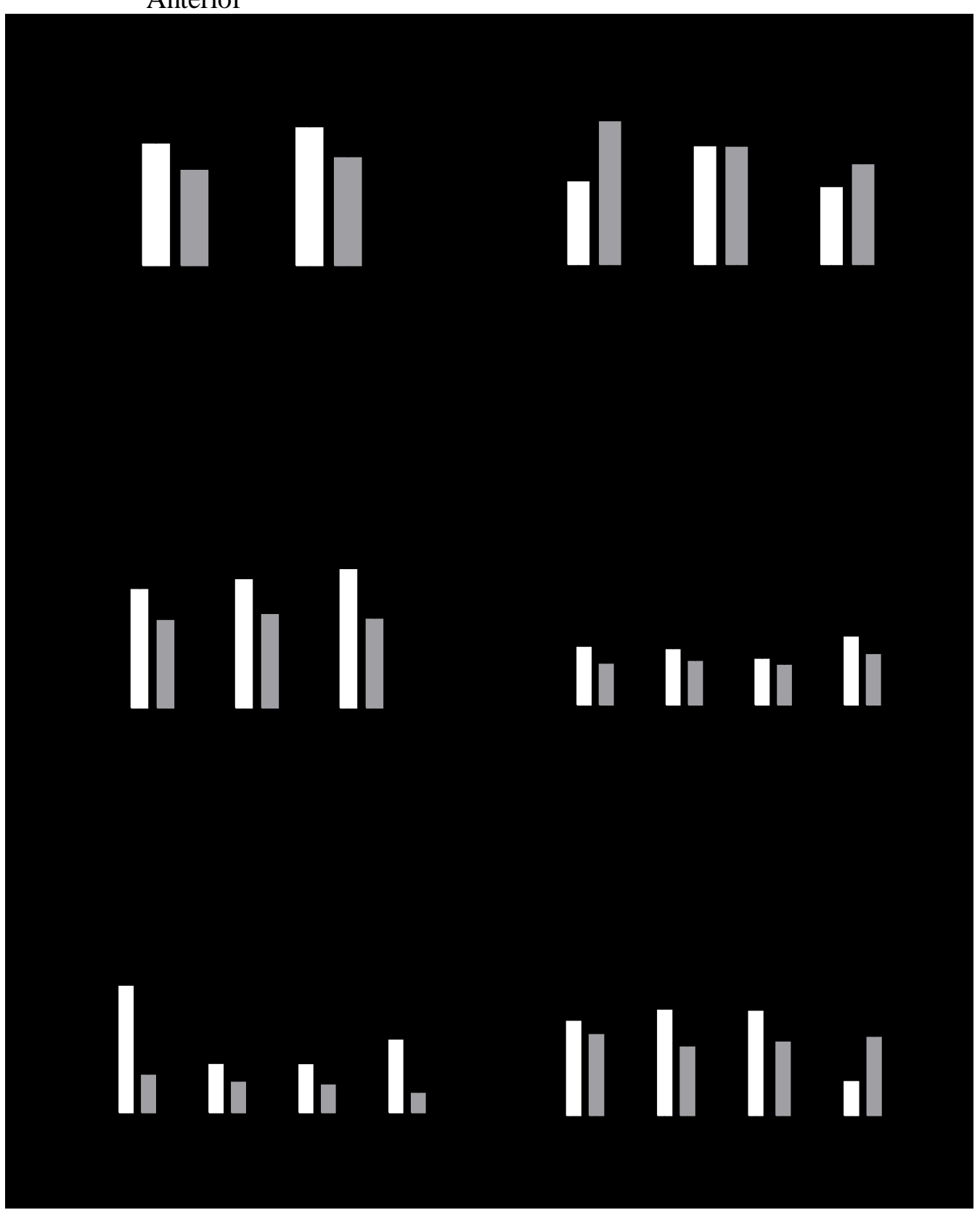

Quantificação da marcação neuronal pela expressão de Fos na PAG de animais implantados na região do córtex motor correspondente à Pata Anterior. A área representada é a PAG divida em níveis A, B, C, D, E e F (sentido rostral-caudal). O grupo estimulado (Est) corresponde aos animais estimulados eletricamente. $\mathrm{O}$ grupo não estimulado $(\mathrm{Ne})$ corresponde aos animais implantados na mesma área, mas não estimulados. O grupo branco $(\mathrm{Bco})$ corresponde aos animais sem intervenção cirúrgica (grupo controle). Os dados representam a média \pm e.p.m. de 2-5 animais por grupo. * p<0,05 em relação ao grupo $\mathrm{Ne}$. 
Figura 20 - Fotomicrografia de secções da PAG submetidas à imunohistoquímica para Fos de ratos implantados na região do córtex motor correspondente à Pata Anterior

\section{Nível B}

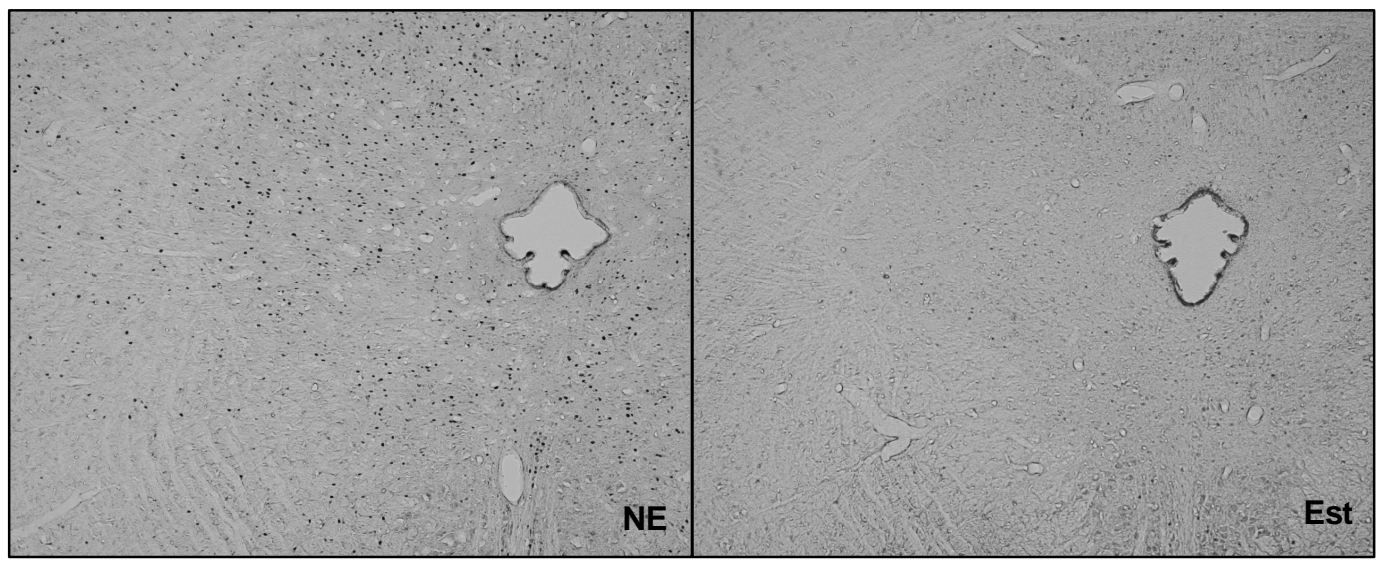

\section{Nível E}

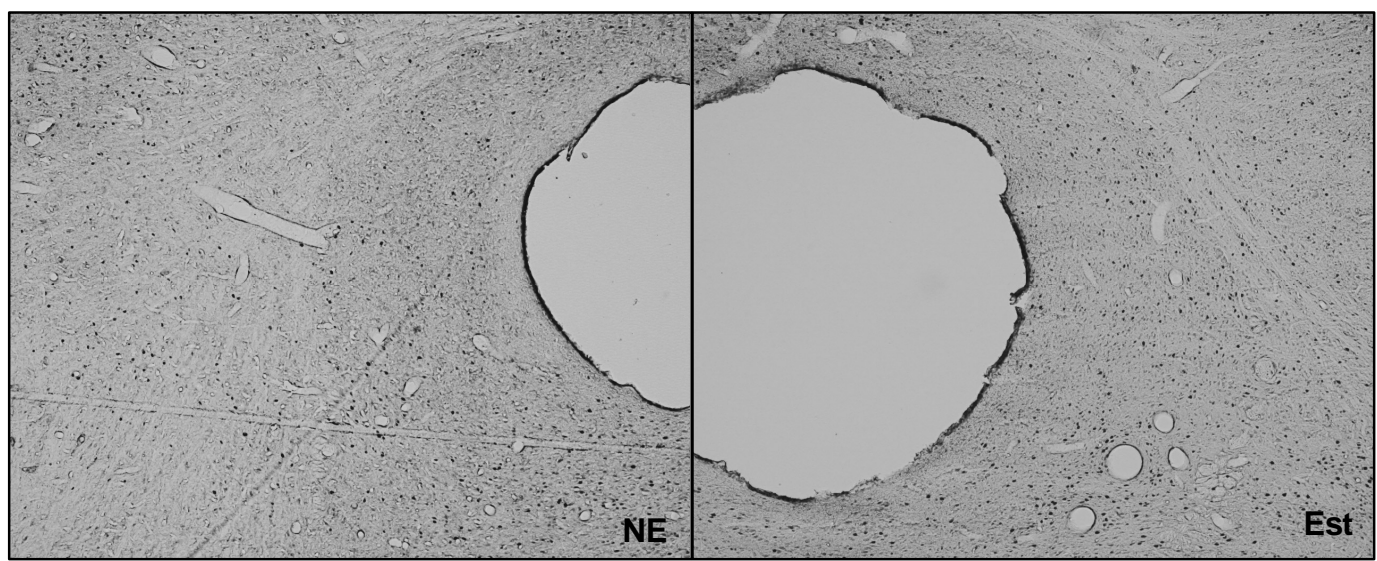

Fotomicrografia de secções da PAG submetidas à imunohistoquímica para Fos de ratos implantados na região do córtex motor correspondente à Pata Anterior com alterações significativas no padrão de expressão. Os eletrodos corticais foram implantados no hemisfério esquerdo. NE: cortes obtidos de animais implantados na mesma área, mas não estimulados. Est: cortes obtidos de animais implantados e estimulados eletricamente. Escala $(-)=50 \mu \mathrm{m}$. 
Figura 21 - Quantificação da marcação neuronal pela expressão de Fos na PAG de animais implantados na região do córtex motor correspondente à Cauda

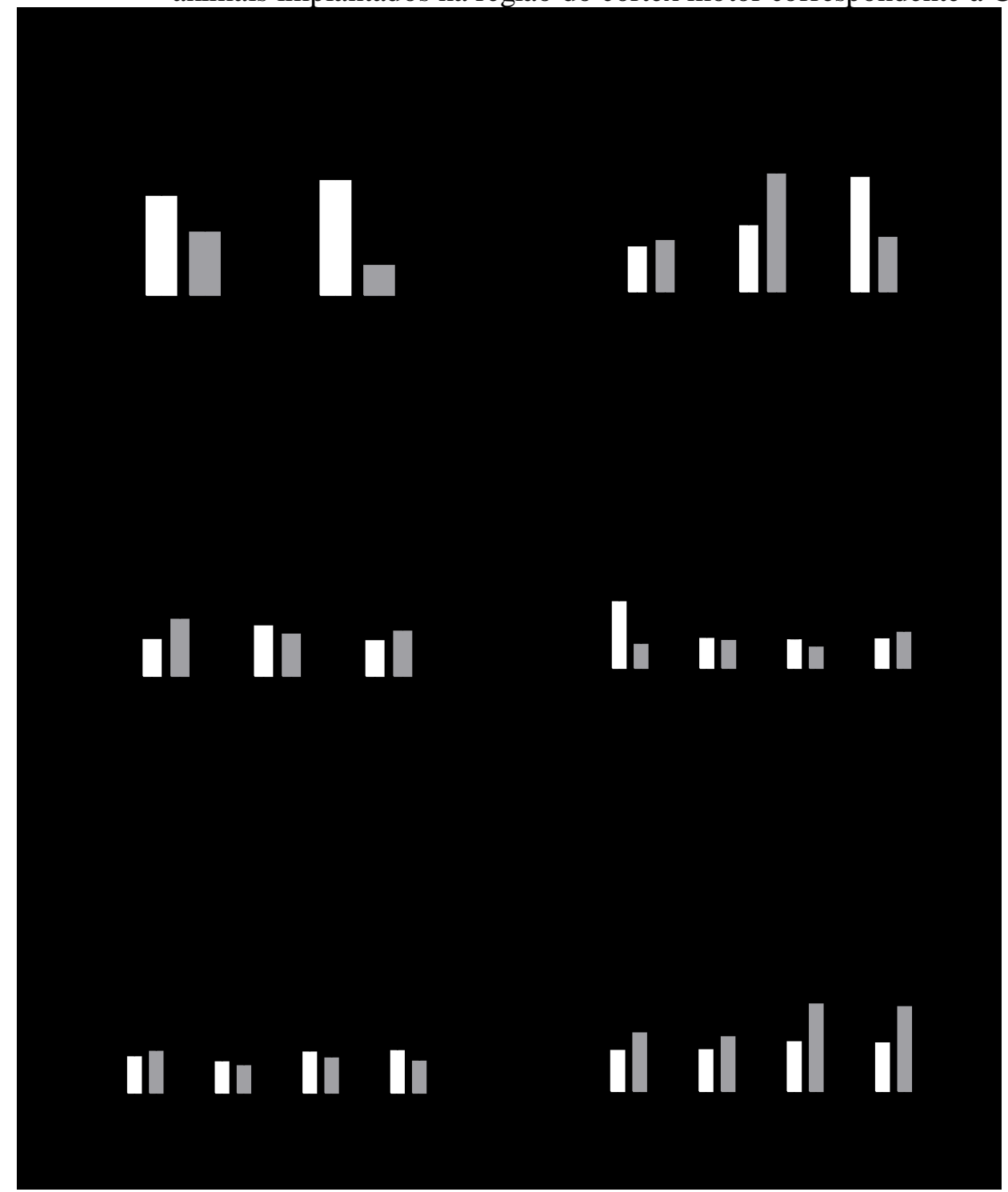

Quantificação da marcação neuronal pela expressão de Fos na PAG de animais implantados na região do córtex motor correspondente à Cauda. A área representada é a PAG divida em níveis A, B, C, D, E e F (sentido rostral-caudal). O grupo estimulado (Est) corresponde aos animais estimulados elétricamente. $\mathrm{O}$ grupo não estimulado $(\mathrm{Ne})$ corresponde aos animais implantados na mesma área, mas não estimulados. O grupo branco (Bco) corresponde aos animais sem intervenção cirúrgica (grupo controle). Os dados representam a média \pm e.p.m. de 2-5 animais por grupo. 
Figura 22 - Quantificação da marcação neuronal pela expressão de Egr-1 na PAG

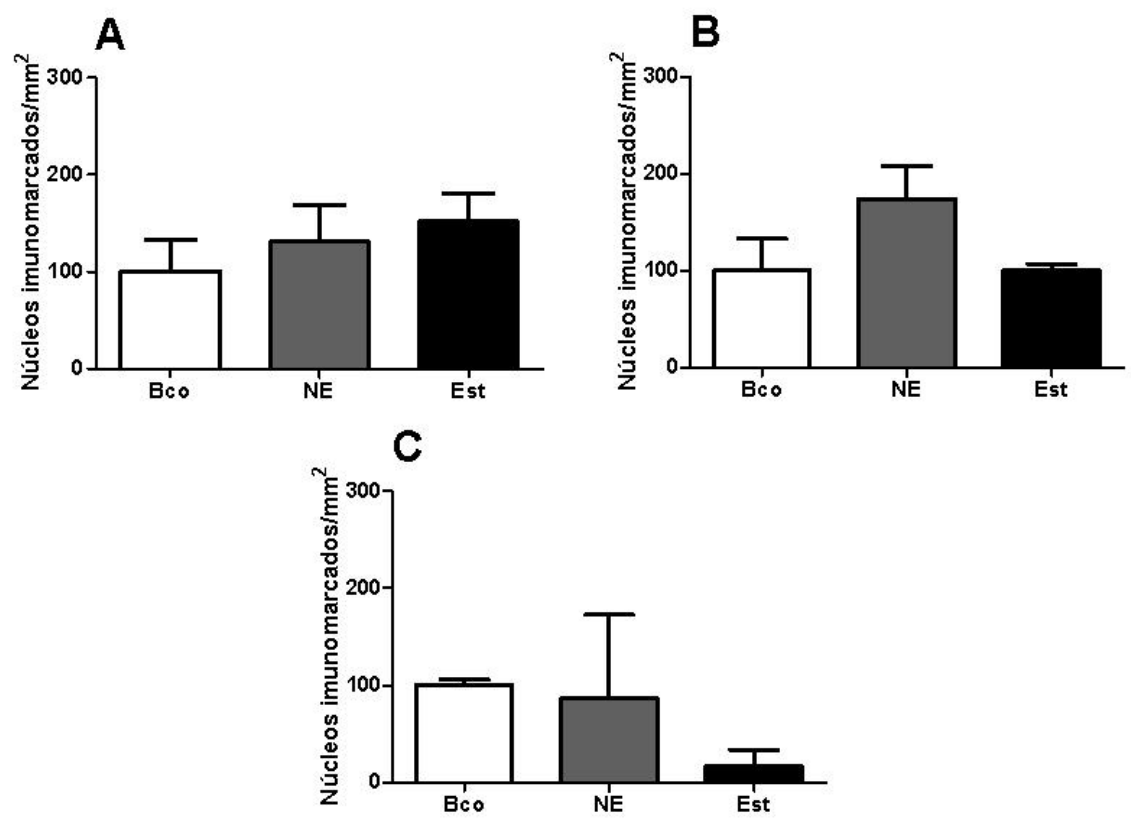

Quantificação da marcação neuronal pela expressão de Egr-1 na PAG de animais implantados na região do córtex motor nas áreas correspondentes a: (A) pata posterior, (B) pata anterior e (C) cauda. O grupo branco (Bco) corresponde aos animais sem intervenção cirúrgica. O grupo não estimulado (NE) corresponde aos animais implantados, mas não estimulados (grupo controle) e o grupo estimulado (Est) corresponde aos animais implantados e estimulados eletricamente. Os dados representam a média \pm e.p.m. de 3-5 animais por grupo. 
Figura 23 - Quantificação da marcação neuronal pela expressão de Egr-1 na PAG de animais implantados na região do córtex motor correspondente à Pata Posterior

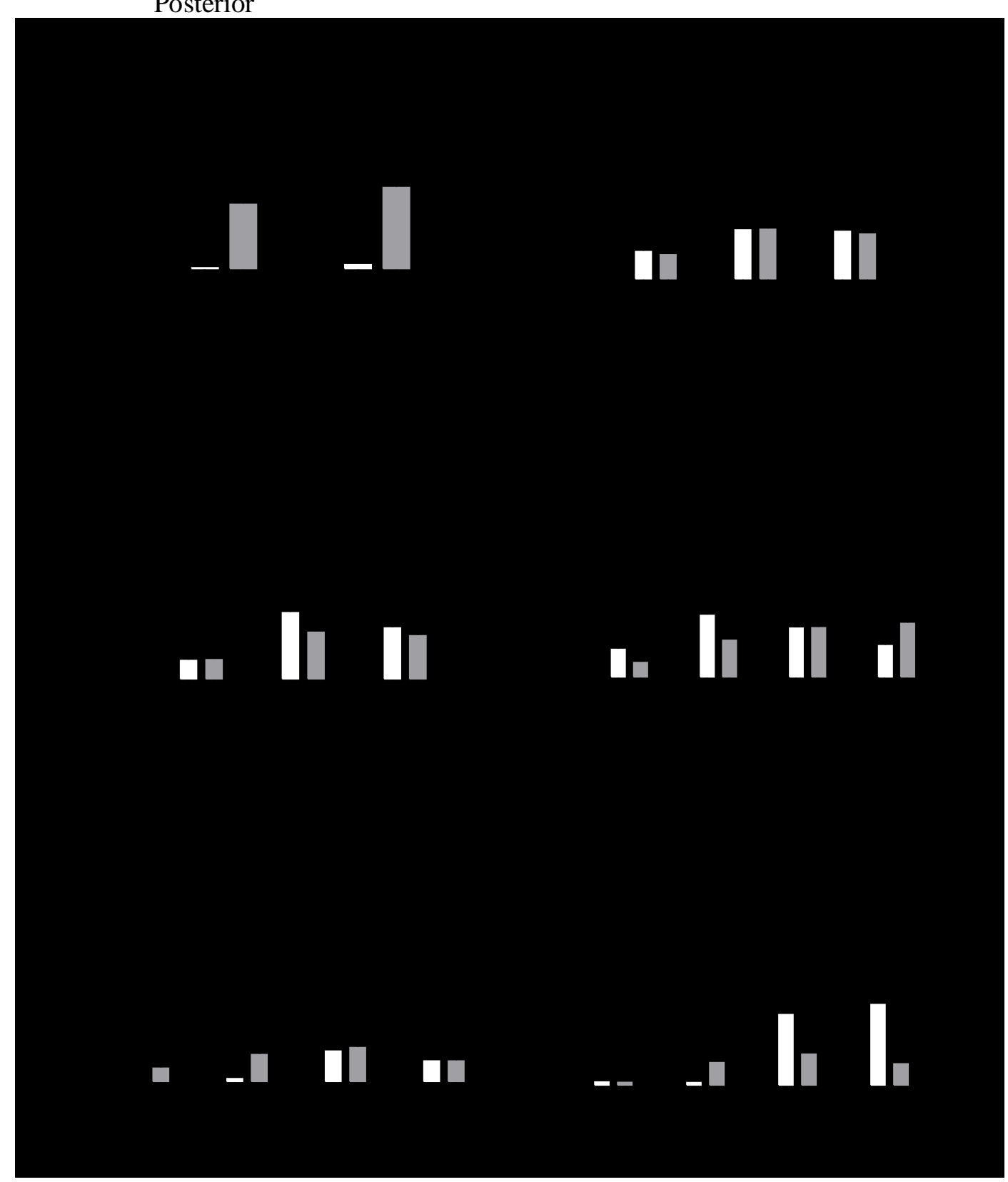

Quantificação da marcação neuronal pela expressão de Egr-1 na PAG de animais implantados na região do córtex motor correspondente à Pata Posterior. A área representada é a PAG divida em níveis A, B, C, D, E e F (sentido rostral-caudal). O grupo estimulado (Est) corresponde aos animais estimulados elétricamente. $\mathrm{O}$ grupo não estimulado $(\mathrm{Ne})$ corresponde aos animais implantados na mesma área, mas não estimulados. O grupo branco (Bco) corresponde aos animais sem intervenção cirúrgica (grupo controle). Os dados representam a média \pm e.p.m. de 2-5 animais por grupo. * $\mathrm{p}<0,05 \mathrm{e} * * \mathrm{p}<0,001$ em relação ao grupo $\mathrm{Ne}$. 
Figura 24 - Fotomicrografia de secções da PAG submetidas à imunohistoquímica para Egr-1 de ratos implantados na região do córtex motor correspondente à Pata Posterior

\section{Nível E}

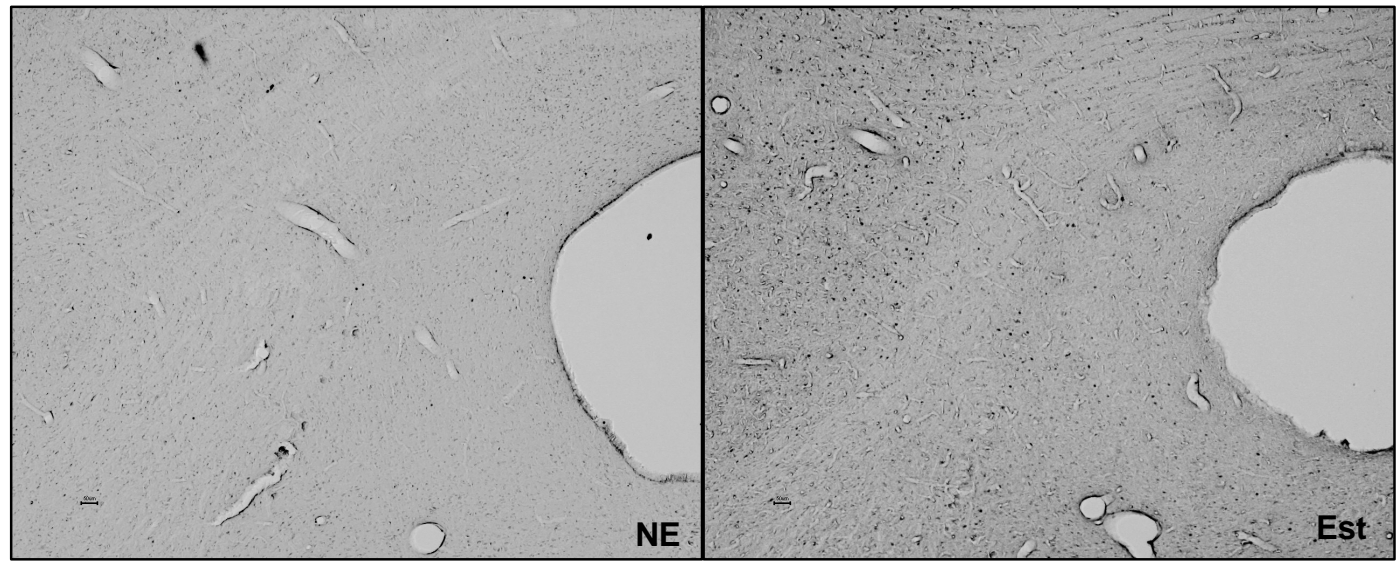

Fotomicrografia de secções da PAG submetidas à imunohistoquímica para Egr-1 de ratos implantados na região do córtex motor correspondente à Pata Posterior com alterações significativas no padrão de expressão. Os eletrodos corticais foram implantados no hemisfério esquerdo. NE: cortes obtidos de animais implantados na mesma área, mas não estimulados. Est: cortes obtidos de animais implantados e estimulados eletricamente. Escala $(-)=50 \mu \mathrm{m}$. 
Figura 25 - Quantificação da marcação neuronal pela expressão de Egr-1 na PAG de animais implantados na região do córtex motor correspondente à Pata Anterior

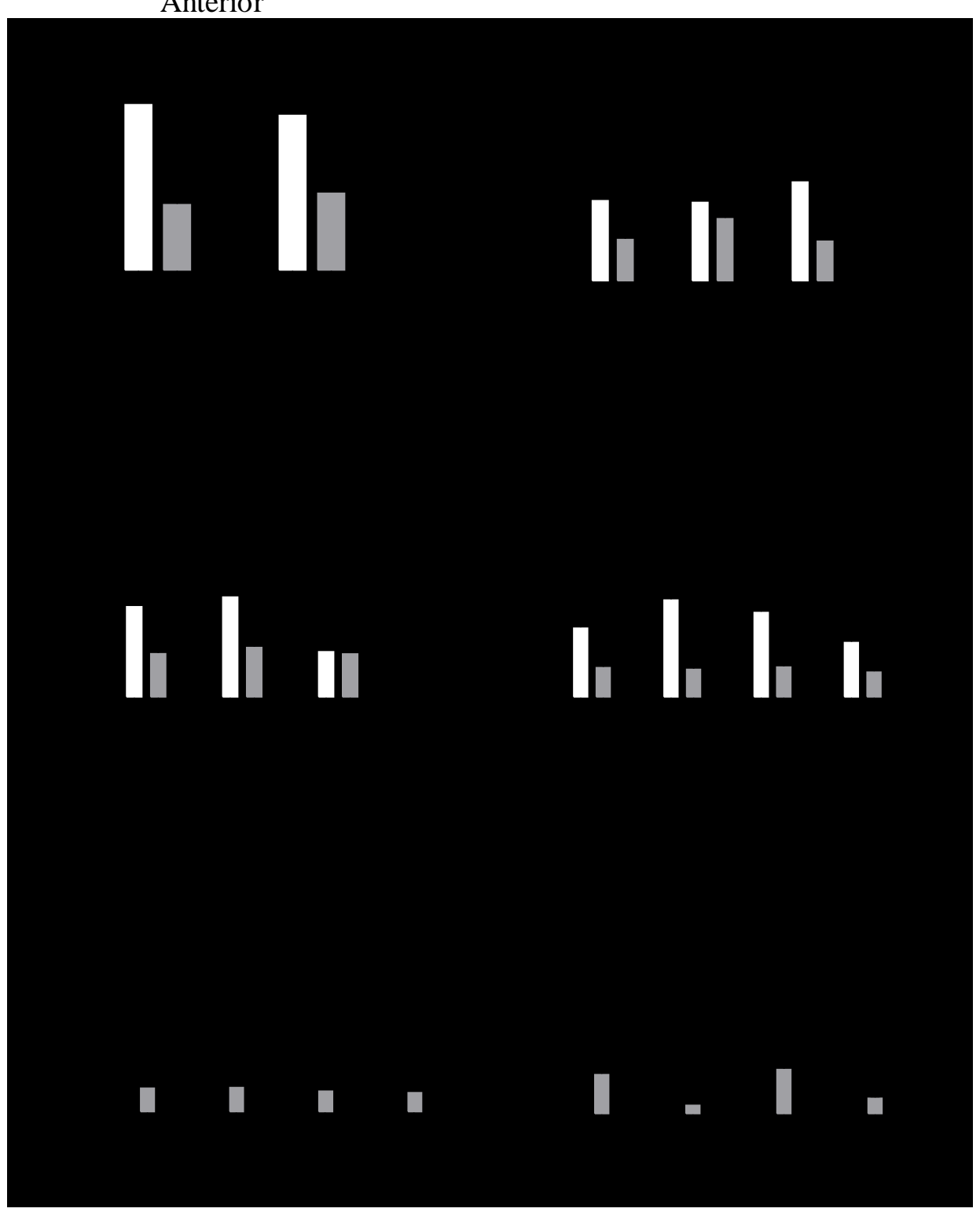

Quantificação da marcação neuronal pela expressão de Egr-1 na PAG de animais implantados na região do córtex motor correspondente à Pata Anterior. A área representada é a PAG divida em níveis A, B, C, D, E e F (sentido rostral-caudal). O grupo estimulado (Est) corresponde aos animais estimulados elétricamente. $\mathrm{O}$ grupo não estimulado $(\mathrm{Ne})$ corresponde aos animais implantados na mesma área, mas não estimulados. O grupo branco (Bco) corresponde aos animais sem intervenção cirúrgica (grupo controle). Os dados representam a média \pm e.p.m. de 2-5 animais por grupo. $* \mathrm{p}<0,05$ em relação ao grupo $\mathrm{Ne}$. 
Figura 26 - Fotomicrografias de secções da PAG submetidas à imunohistoquímica para Egr-1 de ratos implantados na região do córtex motor correspondente à Pata Anterior

\section{Nível E}

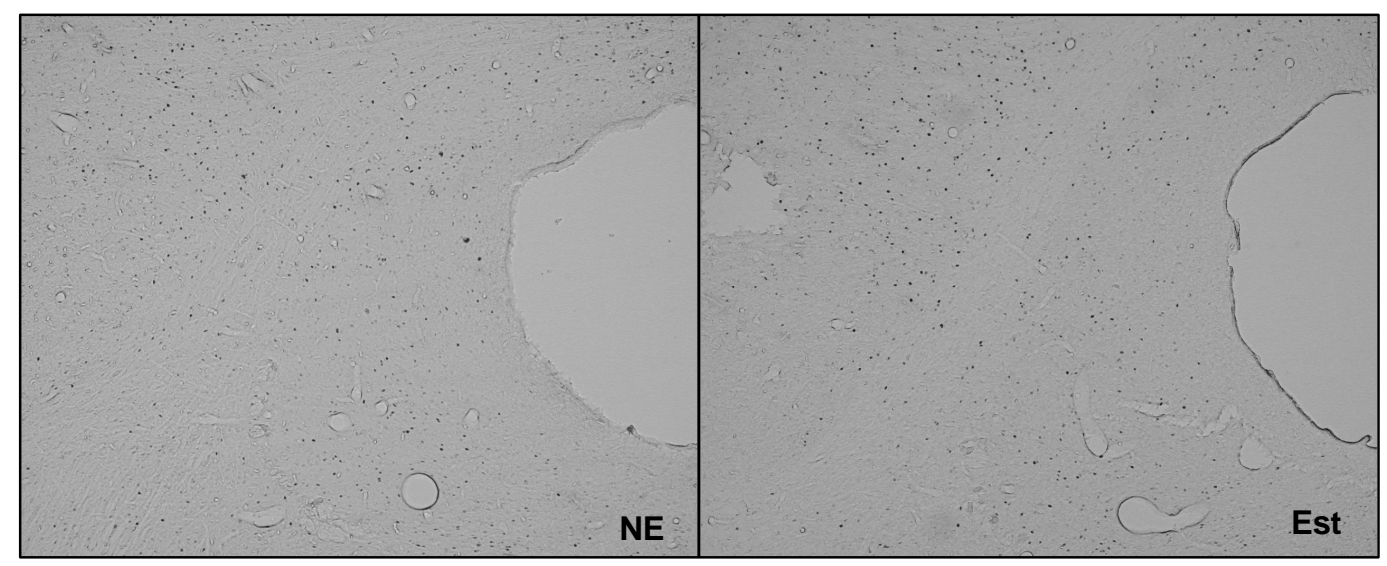

Fotomicrografias de secções da PAG submetidas à imunohistoquímica para Egr-1 de ratos implantados na região do córtex motor correspondente à Pata Anterior com alterações significativas no padrão de expressão. Os eletrodos corticais foram implantados no hemisfério esquerdo. NE: cortes obtidos de animais implantados na mesma área, mas não estimulados. Est: cortes obtidos de animais implantados e estimulados eletricamente. Escala $(-)=50 \mu \mathrm{m}$. 
Figura 27 - Quantificação da marcação neuronal pela expressão de Egr-1 na PAG de animais implantados na região do córtex motor correspondente à Cauda

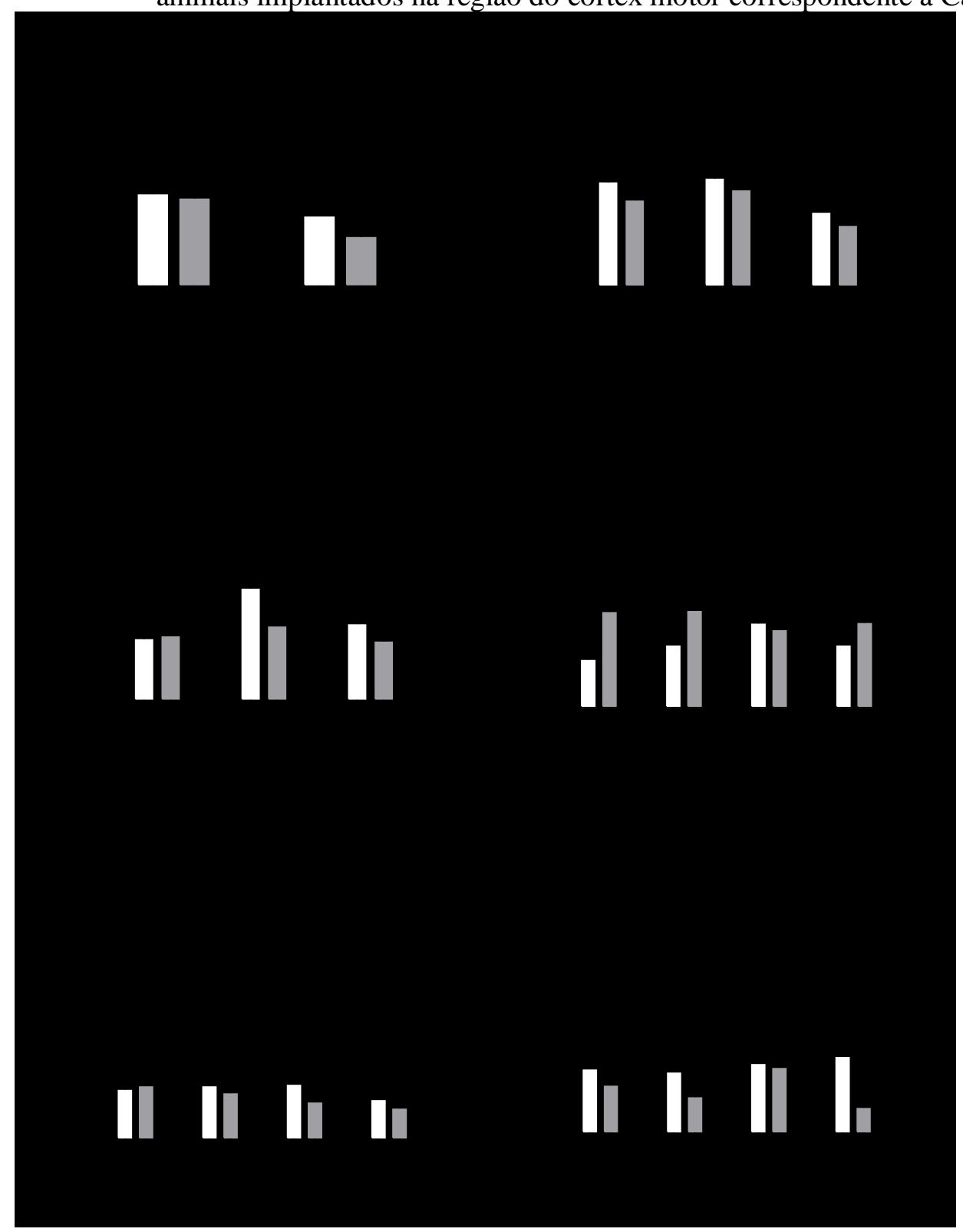

Quantificação da marcação neuronal pela expressão de Egr-1 na PAG de animais implantados na região do córtex motor correspondente à Cauda. A área representada é a PAG divida em níveis A, B, C, D, E e F (sentido rostral-caudal). O grupo estimulado (Est) corresponde aos animais estimulados elétricamente. $\mathrm{O}$ grupo não estimulado $(\mathrm{Ne})$ corresponde aos animais implantados na mesma área, mas não estimulados. O grupo branco (Bco) corresponde aos animais sem intervenção cirúrgica (grupo controle). Os dados representam a média \pm e.p.m. de 2-5 animais por grupo. 


\section{DISCUSSÃO}

As propriedades antinociceptivas da ECM vêm sendo demonstradas no tratamento de algias de diferentes origens (Fagundes-Pereyra et al., 2010; Lefaucheur et al., 2001, 2009; Meyerson et al., 1993; Nguyen et al., 1997; Nuti et al., 2005) . No entanto, embora a utilização clínica desta técnica venha crescendo nos últimos anos, pouco se sabe sobre os mecanismos que envolvem este efeito.

Dados obtidos pelo nosso grupo demonstram que a ECM induz antinocicepção tanto em roedores normais quanto com dor neuropática, sem interferir com a resposta motora destes animais (Fonoff et al., 2009a; Pagano et al., 2011). Foi também demonstrado por estes autores que o efeito analgésico induzido pela ECM é específico para a região do córtex motor uma vez que a estimulação elétrica do córtex somatossensorial não foi capaz de induzir alterações significativas no limiar nociceptivo dos animais (Fonoff et al., 2009a).

A literatura indica que o efeito da estimulação cortical no tratamento da dor tem relação com a somatotopia do córtex motor (Canavero, Bonicalzi, 1995), uma vez que foi sugerido que a ECM ativa neurônios não-nociceptivos que estabelecem conexões recíprocas entre os córtices motor e sensitivo, e restaura os mecanismos inibitórios que atuam em neurônios nociceptivos corticais hiperativos (Tsubokawa, Katayama, 1998). Partindo destas observações o presente projeto avaliou a relação entre o efeito antinociceptivo induzido pela ECM e a somatotopia do córtex motor peribregmático. Os modelos de nocicepção empregados neste trabalho foram métodos comportamentais distintos cujos estímulos produzem respostas mecânicas que envolvem os centros superiores do sistema nervoso central (Bianchi e Franceschini, 1954; Fonoff et al., 2009a; Herr et al., 1952; Randall e Sellitto, 1957).

Os resultados aqui obtidos demonstram que o efeito antinociceptivo induzido pela ECM apresenta relação topográfica entre a área do córtex motor estimulada e o membro avaliado, uma vez que as alterações comportamentais foram observadas apenas no membro correspondente à área motora estimulada sem interferir com as regiões adjacentes do corpo. Esses dados corroboram com resultados da literatura obtidos em humanos que demonstram que o efeito da ECM no tratamento da dor está relacionado com a somatotopia do córtex motor, cujos melhores resultados são observados quando o paciente é estimulado na área especificamente relacionada ao segmento acometido pela dor (Canavero, Bonicalzi, 1995). Outro dado importante foi o fato de o efeito 
antinociceptivo induzido pela ECM no modelo escolhido não apresentar gradiente de efeito, ou seja, a estimulação de uma área não foi capaz de afetar regiões do corpo mais próximas à estimulada. Esses resultados podem ter relevância aplicada, por exemplo, auxiliando futuramente na escolha de alvos para a estimulação, pois em humanos há casos de dores que se estendem sobre uma região corporal grande, mas em que se deve escolher uma área alvo única para a estimulação.

A literatura demonstra que a analgesia gerada pela estimulação cortical em animais com dor neuropática, inibe a ativação neuronal na CPME, nos neurônios sensoriais do tálamo e aumenta a ativação neuronal na PAG (Pagano et al., 2011). Partindo destas observações e com o objetivo de se determinar a possível somatotopia das vias neurais envolvidas no efeito antinociceptivo induzido pela ECM, avaliou-se o perfil de ativação neuronal na CPME e na PAG dos animais, áreas que sabidamente estão envolvidas na modulação da dor (Afifi, Bergman, 2007).

Inicialmente foi avaliado o padrão de expressão das proteínas Fos e Egr-1 na CPME dos animais estimulados na área do córtex motor correspondente às Patas Posterior, Anterior e Cauda. Os resultados demonstraram uma diminuição significativa da expressão da proteína Fos na CPME dos animais submetidos à ECM nos diferentes grupos avaliados. Esses dados corroboram com dados de eletrofisiologia que demonstram a inibição de neurônios espinais de amplo espectro dinâmico, em resposta à estimulação mecânica após ECM subdural (Senapati et al., 2005a) e com dados que demonstram inibição da ativação neuronal na CPME de ratos com neuropatia periférica e submetidos à ECM (Pagano et al., 2011). Ainda, estes autores sugerem que a ECM reduz a dor neuropática em modelo experimental por uma inibição da transmissão do estímulo nocivo na medula espinal por meio de uma ativação do sistema inibidor de dor (Pagano et al., 2011). Os resultados aqui apresentados corroboram com estes dados uma vez que foi observada, uma inibição da ativação neuronal na medula espinal induzida pela ECM, independente da área motora estimulada. Com relação à expressão de Egr-1, os dados obtidos não demonstraram diferença significativa dos diferentes grupos avaliados. No entanto, uma análise mais específica da expressão de Fos e Egr-1 na medula espinal, avaliando-se a expressão dos proto-oncogenes nas diferentes lâminas da medula demonstrou que a inibição na ativação neuronal pôde ser observada tanto para Fos quanto para Egr-1 na região correspondente às lâminas superficiais (I-IV) não sendo observada nenhuma alteração do padrão de ativação tanto de Fos quanto de Egr-1 nas lâminas profundas. 
A arquitetura neuronal da substância cinzenta espinal é composta por diversas populações neuronais, sendo que células do mesmo tipo normalmente encontram-se agrupadas. Em 1952, Rexed demonstrou que os agrupamentos celulares na medula espinal estavam dispostos com extrema regularidade em dez zonas ou lâminas a partir do ápice da coluna posterior e seguindo-se anteriormente para dentro da coluna anterior. As lâminas I a IV estão associadas a sensibilidades exteroceptivas, e recebem as terminações das fibras A-delta e C, que transmitem o impulso nociceptivo. Já as lâminas V e VI estão relacionadas principalmente a sensibilidades proprioceptivas, estado físico do corpo (posição e equilíbrio), embora também respondam a estímulos cutâneos (Afifi, Bergman, 2007; Kiernan, 2003). Os resultados aqui apresentados reforçam a hipótese de que a ECM induz analgesia pela inibição da transmissão do impulso nociceptivo na medula espinal, diretamente no local de entrada dos aferentes primários onde foi observada a diminuição do padrão de expressão da ativação neuronal nos diferentes grupos avaliados.

Além do padrão de ativação neuronal na medula, foi também avaliado o padrão de ativação neuronal na PAG, estrutura também envolvida na modulação da dor (Afifi, Bergman, 2007; Comoli et al., 2003; Ruiz-Torner, 2001). Os resultados obtidos demonstram que a ECM induziu diminuição na expressão de Fos significante apenas para o grupo de animais implantados na área da pata posterior, não sendo observada significância para os outros grupos avaliados. Este aumento corrobora com dados da literatura que demonstram aumento da expressão deste proto-oncogene em animais com dor neuropática e submetidos à ECM (Pagano et al., 2011). No entanto, uma análise mais aprofundada demonstrou diminuição significativa no nível E para os três grupos avaliados

Com base em sua citoarquitetura funcional a PAG é subdividida de forma radial em quatro regiões distintas: dorsomedial, dorsolateral, lateral e ventrolateral, cada uma delas formando uma coluna ao longo do eixo rostro-caudal. Cada região aparenta ter algumas características distintas entre si no que diz respeito à imunorreatividade celular, densidade de receptores, conexões aferentes e eferentes e função (Bandler et al., 1991; Bandler, Depaulis, 1991; Blander, Keay, 1996; Vianna, Brandao, 2003). Ao longo do eixo rostrocaudal também existem diferenças, por isso alguns trabalhos demonstram a importância de se considerar todas as dimensões (divisões em regiões e no eixo rostralcaudal) nos estudos que consideram esta estrutura. Considerando este fato, realizou-se uma análise mais detalhada da PAG, seguindo uma divisão dessa região em 
6 níveis de secção (sentido rostral-caudal) e ainda seguindo as divisões em colunas que cada nível apresenta (Comoli et al., 2003; Ruiz-Torner, 2001). Como citado acima, os resultados obtidos demonstraram um aumento significativo no padrão de expressão Fos no nível E, caudal, para os três grupos avaliados (pata posterior, pata anterior e cauda), sendo esta alteração no nível mais caudal da PAG, observada em todas as colunas, demonstrando um aumento da atividade dos neurônios desta região.

A literatura associa a região lateral da PAG ao aumento da atividade somatomotora e analgesia não-opióide e demonstra que projeções da região lateral e dorsolateral do hipotálamo atingem parte das colunas laterais e ventrolaterais desta estrutura (Kiernan, 2003; Ruiz-Torner, 2001). Resultados semelhantes foram observados para Egr-1 que embora na análise geral não tenha apresentado diferenças estatítiscas para os diferentes grupos, apresentou aumento na expressão de Egr-1 no nível E para as diferentes colunas avaliadas.

Os dados aqui obtidos corroboram com dados recentes obtidos pelo nosso grupo que demonstram que a ECM de ratos normais induz aumento da atividade elétrica de neurônios da PAG, avaliado por eletrofisiologia, bem como aumento na imunorreatividade para Fos na PAG (Pagano et al., 2012 In press.). A hipótese para explicar o efeito analgésico induzido pela ECM é de que a analgesia observada ocorra por uma inibição de interneurônios gabaérgicos com subseqüente ativação de neurônios responsáveis pelo sistema de controle inibitório descendente de dor (Pagano et al., 2012 In press.).

Com base nestas informações é plausível sugerir que a ECM utilizada em nossos experimentos induz analgesia por meio da ativação da via inibitória descendente da dor. A literatura explica que esta via é formada pela PAG, que recebe axônios provenientes do hipotálamo e tem neurônios que se projetam no núcleo magno da rafe, este por sua vez tem axônios de neurônios serotoninérgicos que se projetam na CPME e no núcleo espinal do trigêmeo (Afifi, Bergman, 2007; Kiernan, 2003).

Conforme mencionado anteriormente nos grupos experimentais além do aumento da expressão de Fos no nível $\mathrm{E}$ foi observada uma diminuição deste protooncogene no nível $\mathrm{B}$, nível rostral. A região rostral da $\mathrm{PAG}$ aparentemente não é ativada por qualquer estressor físico como dor cutânea e visceral (Keay, Bandler, 2001) o que permite elucidar que na analgesia induzida pela ECM tem-se a participação de áreas envolvidas com a transmissão ou inibição da dor. Neste caso a CPME, envolvida 
na transmissão da informação nociceptiva para os centros superiores do SNC e a região caudal da PAG que participa da via inibitória descendente da dor.

Em conjunto, os dados obtidos até o momento demonstram que a estimulação do córtex motor induz analgesia em ratos e que este efeito tem relação topográfica com a área do córtex estimulada. Ainda, os resultados aqui apresentados permitem sugerir que o efeito antinociceptivo induzido pela ECM ocorra por uma inibição da transmissão do estímulo nocivo na medula espinal e pela ativação do sistema analgésico endógeno via PAG. Por fim, nossos resultados reforçam a idéia de que o córtex motor está envolvido nos circuitos neurais de controle endógeno da dor. Ainda, embora o mecanismo preciso de ação da ECM ainda não seja conhecido, demonstramos aqui que existem alterações regionais na atividade sináptica observadas pelas alterações na ativação neuronal. Em conjunto, estes dados são uma importante contribuição para o entendimento das vias neuronais envolvidas na analgesia induzida pela estimulação do córtex motor. 


\section{CONCLUSÃO}

A partir dos resultados obtidos com este trabalho concluiu-se que:

- a técnica de ECM, utilizada neste trabalho, induz analgesia em ratos tendo este efeito relação topográfica com cada área do córtex estimulada, uma vez que nos testes comportamentais foram observadas alterações no limiar nociceptivo, significando analgesia, apenas no teste correspondente ao membro cuja área representativa no córtex motor estava sendo estimulada;

- a analgesia induzida pela ECM não apresenta gradiente de efeito considerando-se que durante a estimulação não foram observadas alterações comportamentais em regiões adjacentes do corpo;

- o efeito analgésico obtido durante a ECM é mediado pela inibição da transmissão nociceptiva pelos aferentes primários. Visto que foi observada uma inibição da expressão da proteína Fos e Egr-1nas lâminas superficiais da CPME, o que indica redução na atividade dos neurônios desta região;

- a analgesia induzida pela ECM ativa a PAG, estrutura que faz parte da via descendente inibitória da dor, é ativada durante a ECM, considerando o aumento da expressão da proteína Fos e Egr-1 em regiões da PAG que estabelecem conexões com o núcleo magno da rafe, e que recebem projeções do hipotálamo, sendo estas estruturas integrantes do sistema de analgesia endógeno. 


\section{REFERÊENIAS*}

Afifi AK, Bergman RA. Neuroanatomia funcional: texto e atlas. 2. ed. São Paulo: Roca; 2007.

Almeida TF, Roizenblatt S, Tufik S. Afferent pain pathways: a neuroanatomical review. Brain Res. 2004;1000:40-56.

Aloisi AM, Albonetti ME, Lodi L, Lupo C, Carli G. Decrease of hippocampal choline acetyltransferase activity induced by formalin pain. Brain Res. 1993;629:167-70.

Altier C, Zamponi GW. Targeting Ca2+ channels to treat pain: T-type versus N-type Trends Pharmacol Sci. 2004;25:465-70.

Amit Z, Galina ZH. Stress-induced analgesia: adaptive pain suppression. Physiol Rev. 1986;66(4):1091-120.

Basbaum AI, Clanton CH, Fields HL. Opiate and stimulus-produced analgesia: functional anatomy of a medullospinal pathway. Proc Natl Acad Sci U S A. 1976;73(12):4685-8.

Basbaum AI, Fields HL. The origin of descending pathways in the dorsolateral funiculus of the spinal cord of the cat and rat: further studies on the anatomy of pain modulation. J Comp Neurol. 1979;187(3):513-31.

Beckmann AM, Wilce PA. Egr transcription factors in the nervous system. Neurochem Int. 1997;31:477-510.

Beitz AJ, Mullett MA, Weiner LL. The periaqueductal gray projections to the rat spinal trigeminal, raphe magnus, gigantocellular pars alpha and paragigantocellular nuclei arise from separate neurons. Brain Res. 1983;288(1-2):307-14.

Bianchi C, Franceschini J. Experimental observations on Haffner's method for testing analgesic drugs. Brit. J. Pharmacol. 1954;9: 280-4.

Bandler R, Depaulis A. Midbrain periaqueductal gray control of defensive behavior in the cat and the rat. In: Depaulis A, Bandler R, editors. The midbrain periaqueductal gray matter. New York: Plenum Press; 1991. p. 175-98.

Bandler R, Carrive P, Depaulis A. Introduction: emerging priciples of organizations of the midbrain periqueductal gray matter. In: Depaulis A, Bandler R, editors. The midbrain periaqueductal gray matter. New York: Plenum Press; 1991. p. 1-8.

Bandler R, Keay K. A Columnar organization in the midbrain periaqueductal gray and the integration of emotional expression. Prog Brain Res. 1996;107:285-300.

\footnotetext{
*De acordo com: International Committee of Medical Journal Editors. [Internet]. Uniform requirements for manuscripts submitted to Biomedical Journal: sample references. [updated 2011 Jul 15]. Available from: http://www.icmje.org.
} 
Brooks J, Tracey I. From nociception to pain perception: imaging the spinal and supraspinal pathways. J Anat. 2005;207(1):19-33.

Buritova J, Honore P, Besson JM. Indomethacin reduces both Krox-24 expression in the rat lumbar spinal cord and inflammatory signs following intraplantar carrageenan. Brain Res. 1995;674:211-20.

Castex N, Fioramonti J, Fargeas MJ, Bueno L. c-fos expression in specific rat brain nuclei after intestinal anaphylaxis: involvement of 5-HT3 receptors and vagal afferent fibers. Brain Res. 1995;688:149-60.

Comoli E, Ribeiro-Barbosa ER,Canteras NS. Predatory hunting and exposure to a live predator induce opposite patterns of Fos immunoreactivity in the PAG. Behavioural Brain Research. 2003;138:17-28.

Craig AD, Dostrovsky JO. Medulla to Thalamus. In: Wall PD, Melzack R, editors. Textbook of pain. Edinburgh: Churchill-Livingstone; 1999. p. 183-214.

Cruccu G, Inghilleri M, Berardelli A, Romaniello A, Manfredi M. Cortical mechanisms mediating the inhibitory period after magnetic stimulation of the facial motor area. Muscle Nerv. 1997;20:418-24.

Denadai-Souza A, Camargo LL, Ribela MTCP, Keeble JE, Costa SKP, Muscará MN. Participation of peripheral tachykinin NK1 receptors in the carrageenan-induced inflammation of the rat temporomandibular joint. Eur J Pain. 2009;13:812-9.

Dewey WL, Snyder JW, Harris LS, Howes JF. The effect of narcotics and narcotic antagonists on the tail-flick response in spinal mice. $J$ Pharm Pharmacol. 1969;21(8):548-50.

Duggan AW, Johnson SM, Morton CR. Differing distributions of receptors for morphine and Met5-enkephalinamide in the dorsal horn of the cat. Brain Res. 1981; 229(2):379-87.

Fagundes-Pereyra WJ, Teixeira MJ, Reyns N, Touzet G, Dantas S, Laureau E, Blond S. Motor cortex electric stimulation for the treatment of neuropathic pain. Arq. Neuropsiquiatr. 2010;68:923-9.

Falconer MA. Surgical treatment of intractable phantom-limb pain. Br Med J. 1953; 1(4805):299-304.

Fonoff ET, Dale CS, Pagano RL, Paccola CC, Ballester G, Teixeira MJ, Giorgi R. Antinociception induced by epidural motor cortex stimulation in naive conscious rats is mediated by the opioid system. Behav Brain Res. 2009a;196:63-70.

Fonoff ET, Pereira JF Jr, Camargo LV, Dale CS, Pagano RL, Ballester G, Teixeira MJ.Functional mapping of the motor cortex of the rat using transdural electrical stimulation. Behav Brain Res. 2009b;202:138-41. 
Gauriau C, Bernard JF. Pain pathways and parabrachial circuits in the rat. Exp Physiol. 2002;87:251-8.

Gogas KR, Presley RW, Levine JD, Basbaum AI. The antinociceptive action of supraspinal opioids results from an increase in descending inhibitory control: correlation of nociceptive behavior and c-fos expression. Neuroscience. 1991;42:61728.

Gojyo F, Sugiyo S, Kuroda R, Kawabata A, Varathan V, Shigenaga Y, Takemura M. Effects of somatosensory cortical stimulation on expression of c-Fos in rat medullary dorsal horn in response to formalin-induced noxious stimulation. J. Neurosci Res. 2002;68:479-88.

Harris JA. Descending antinociceptive mechanisms in the brainstem: their role in the animal's defensive system. J. Physiol Paris.1996;90(1):15-25.

Harris JA. Using c-fos as a neural marker of pain. Brain Res. Bull. 1998;45:1-8.

Herdegen T, Kovary K, Leah J, Bravo R. Specific temporal and spatial distribution of JUN, FOS, and KROX-24 proteins in spinal neurons following noxious transsynaptic stimulation. J Comp Neurol. 1991;313:178-91.

Herdegen T, Leah JD. Inducible and constitutive transcription factors in the mammalian nervous system: control of gene expression by Jun, Fos and Krox, and CREB/ATF proteins. Brain Res Rev. 1998;28:370-490.

Hermanson O, Blumqvist A. Subnuclear localization of FOS-like immunoreactivity in the rat parabrachial nucleus after nociceptive stimulation. J. Comp. Neurol. 1996;368:45-56.

Herr F, Nyiri M, Venulet J. Studies on the mode of analgesic action of morphine and morphine derivatives. Acta Physiol Hung. 1952;3(1):199-208.

Honkaniemi J. Colocalization of peptide- and tyrosine hydroxylase-like immunoreactivities with Fos-immunoreactive neurons in rat central amygdaloid nucleus after immobilization stress. Brain Res. 1992;598(1-2):107-13.

Hunt SP, Pini A, Evan G. Induction of c-fos-like protein in spinal cord neurons following sensory stimulation. Nature. 1987;328:632-4.

Jessel TM, Kelly DD. Pain and analgesia. In: Kandel E, Schwartz JH, Jessel TM, editors. Principles of neural science. USA: Elsevier; 1991. p. 385-99.

Jones SL. Descending noradrenergic influences on pain. Prog Brain Res. 1991;88:38194. 
Katayama Y, Fukaya C, Yamamoto T. Poststroke pain control by chronic motor cortex stimulation: neurological characteristics predicting a favorable response. J Neurosurg. 1998;89:585-91.

Keay KA, Bandler R. Deep and superficial noxious stimulation increases Fos-like immunoreactivity in different regions of the midbrain periaqueductal grey of the rat. Neurosci Lett. 1993;154:23-6.

Keay KA, Clement CI, Depaulis A, Bandler R. Different representations of inescapable noxious stimuli in the periaqueductal gray and upper cervical spinal cord of freely moving rats. Neurosci Lett. 2001;313:17-20.

Keay KA, Bandler R. Parallel circuits mediating distinct emotional coping reactions to different types of stress. Neurosci Biobehav Rev. 2001;25:669-78.

Kiernan JA. Neuroanatomia humana de Barr. 7. ed. São Paulo: Manole; 2003.

Kober F, Ilti I, Cozzone PJ, Bernard M. Myocardial blood flow mapping in mice using high-resolution spin labeling magnetic resonance imaging: influence of ketamine/xylazine and isoflurane anesthesia. Magn Reson Med. 2005;53:601-6.

Krout KE, Belzer RE, Loewy AD. Brainstem projections to midline and intralaminar thalamic nuclei of the rat. J. Comp. Neurol. 2002;448(1):53-101.

Kuroda R, Kawabata A, Kawao N, Umeda W, Takemura M, Shigenaga Y. Somatosensory cortex stimulation-evoked analgesia in rats: potentiation by NO synthase inhibition. Life Sciences. 2000;66:271-6.

Kuroda R, Kawao N, Yoshimura H, Umeda W, Takemura M, Shigenaga

Y, Kawabata A. Secondary somatosensory cortex stimulation facilitates the antinociceptive effect of the NO synthase inhibitor through suppression of spinal nociceptive neurons in the rat. Brain Res. 2001;903:110-6.

Lee Y, Lee CH, Oh U. Painful channels in sensory neurons. Mol Cells. 2005;20:31524.

Lefaucheur JP, Drouot X, Nguyen JP. Interventional neurophysiology for pain control: duration of pain relief following repetitive transcranial magnetic stimulation of the motor cortex. Neurophysiol Clin. 2001;31(4):247-52.

Lefaucheur JP, Drouot X, Cunin P, Bruckert R, Lepetit H, Créange A, Wolkenstein P, Maison P, Keravel Y, Nguyen JP. Motor cortex stimulation for the treatment of refractory peripheral neuropathic pain. Brain. 2009;132(6):1463-71. 
Lindblom UF, Ottosson JO. Influence of pyramidal stimulation upon the relay of coarse cutaneous afferents in the dorsal horn. Acta Physiol Scand. 1957;38:309-18.

Loeser JD, Ward Jr AA, White Jr LE. Chronic deafferentation of human spinal cord neurons. J Neurosurg. 1968;29(1):48-50.

Lumb BM. Inescapable and escapable pain is represented in distinct hypothalamicmidbrain circuits: specific roles for Adelta- and C-nociceptors. Exp Physiol. 2002; 87(2):281-6.

Mason P. Contributions of the medullary raphe and ventromedial reticular region to pain modulation and other homeostatic functions. Annu Rev Neurosci. 2001; 24:737-77.

Mayer DJ, Wolfle TL, Akil H, Carder B, Liebeskind JC. Analgesia from electrical stimulation in the brainstem of the rat. Science. 1971;174(16):1351-4.

Melzack R, Wall PD. Pain mechanisms: a new theory. Science. 1965;150:971-9.

Meyerson BA, Lindblom U, Linderoth B, Lind G, Herregodts P. Motor cortex stimulation as treatment of trigeminal neuropathic pain. Acta Neurochir Suppl (wien). $1993 ; 58: 150-3$.

Millan MJ. The induction of pain: an integrative review. Prog Neurobiol. 1999;57(1):1164.

Mineta Y, Eisenberg E, Strassman AM. Distribution of Fos-like immunoreactivity in the caudal medullary reticular formation following noxious facial stimulation in the rat. Exp Brain Res. 1995;107:34-8.

Morgan JI, Curran T. Stimulus-transcription coupling in neurons: role of cellular immediate-early genes. Trends Neurosci. 1989;12:459-62.

Nathan PW. Pain. Br Med Bull. 1977;33(2):149-55.

Nalwalk JW, Koch JE, Barke KE, Bodnar RJ, Hough LB. Modulation of morphine antinociception by the brain-penetrating $\mathrm{H} 2$ antagonist zolantidine: detailed characterization in five nociceptive test systems. Pharm Biochem and Behavior. $1995 ; 50: 421-9$.

Nguyen JP, Keravel Y, Feve A, Uchiyama T, Cesaro P, Le Guerinel C, Pollin B. Treatment of deafferentation pain by chronic stimulation of the motor cortex: report of a series of 20 cases. Acta Neurochir Suppl. 1997;68:54-60.

Nguyen JP, Lefaucher JP, Le Guerinel C, Eizenbaum JF, Nakano N, Carpentier A, Brugières P, Pollin B, Rostaing S, Keravel Y. Motor cortex stimulation in the treatment of central and neuropathic pain. Arq. Med Res. 2000;31:263-5. 
Nuti C, Peyron R, Garcia-Larrea L, Brunon J, Laurent B, Sindou M, Mertens P. Motor cortex stimulation for refractory neuropathic pain: four year outcome and predictors of efficacy. Pain. 2005;118:43-52.

Oleson TD, Liebeskind JC. Relationship of neural activity in the raphe nuclei of the rat to brain stimulation-produced analgesia. Physiologist. 1975;18:338.

Pagano RL, Assis DV, Clara JA, Alves AS, Dale CS, Teixeira MJ, Fonoff ET, Britto LR. Transdural motor cortex stimulation reverses neuropathic pain in rats: A profile of neuronal activation. Eur J Pain. 2011;15:268-74.

Pagano RL, Fonoff ET, Dale CS, Ballester G, Teixeira MJ, Britto LR. Motor cortex stimulation and analgesia: possible pathways and Mechanisms. Pain, 2012. In press

Penfield W, Perot P. The brains record of auditory and visual experience: a final summary and discussion. Brain. 1963,86:595-696.

Pertovaara A, Bravo R, Herdegen T. Induction and suppression of immediate-early genes in the rat brain by a selective alpha-2-adrenoceptor agonist and antagonist following noxious peripheral stimulation. Neuroscience. 1993;54:117-26.

Raja SN, Meyer RA, Ringkamp M, Campbell JN. Peripherial neural mechanisms of nociception. In: Wall PD, Melzack R, editors. Textbook of pain. London: Churchill Livingstone; 1999. p. 11-57.

Randall LO, Sellitto JJ. A method for measurement of analgesic activity on inflamed tissue. Arch Intern Pharmacodyn. 1957;111:209-19.

Reynolds DV. Surgery in the rat during electrical analgesia induced by focal brain stimulation. Science. 1969;164(878):444-5.

Riedel W, Neeck G. Nociception, pain, and antinociception: current concepts. Z Rheumatol. 2001;60:404-15.

Rosenfeld JP. Interacting brain stem components of opiate-activated, descending, paininhibitory systems. Neurosci Biobehav Rev. 1994;18(3):403-9.

Ruiz-Torner A, Olucha-Bordonau F, Valverde-Navarro AA, Martı'nez-Soriano F. The chemical architecture of the rat's periaqueductal gray based on acetylcholinesterase histochemistry: a quantitative and qualitative study. J Chem Neuroanat. 2001;21:295312.

Rusina R, Vaculin S, Yamamotova A, Barek S, Dvorakova H, Rokyta R. The effect of motor cortex stimulation in deafferentated rats. Neuro Endocrinol Lett. 2005;26:283-8.

Sagar SM, Sharp FR, Curran T. Expression of c-fos protein in brain: metabolic mapping at the cellular level. Science. 1988;240:1328-31.

Schnitzler A, Ploner M. Neurophysiology and functional neuroanatomy of pain perception. J Clin Neurophysiol. 2000;17(6):592-603. 
Senapati AK, Huntington PJ, Peng YB. Spinal dorsal horn neuron response to mechanical stimuli is decreased by electrical stimulation of the primary motor córtex. Brain Research. 2005a;1036:173-9.

Senapati AK, Huntington PJ, LaGraize SC, Wilson HD, Fuchs PN, Peng YB. Electrical stimulation of the primary somatosensory cortex inhibits spinal dorsal horn neuron activity. Brain Research. 2005b;1057:134-40.

Snedecor GM. Statistical methods applied to experiments in agriculture and biology. Iowa: The Iowa State University Press Ames; 1956.

Snedecor GM, Cochran WG. Statistical methods. Iowa: the Iowa State University Press Ames; 1974.

Suzuki R, Rygh LJ, Dickenson AH. Bad news from the brain: descending 5-HT pathways that control spinal pain processing. Trends Pharmacol Sci. 2004;25(12):613-7.

Takasaki I, Andoh T, Nojima H, Shiraki K, Kuraishi Y. Gabapentin antinociception in mice with acute herpetic pain induced by herpes simplex virus infection. J Pharmacol Exp Ther. 2001;296:270-5.

Terman GW, Shavit Y, Lewis JW, Cannon JT, Liebeskind JC. Intrinsic mechanisms of pain inhibition: activation by stress. Science. 1984;226(4680):1270-7.

Todd AJ. Neuronal circuitry for pain processing in the dorsal horn. Nature reviews. Neuroscience. 2010;11(12):823-36.

Tsubokawa T, Yamamoto T, Katayama Y, Hirayama T, Maejima S, Moriya T. Deepbrain stimulation in a persistent vegetative state: follow-up results and criteria for selection of candidates. Brain Injury. 1990;4:315-27.

Tsubokawa T, Katayama Y, Yamamoto T, Hirayama T, Koyama S. Treatment of thalamic pain by chronic motor cortex stimulation. Pacing Clin Electrophysiol. $1991 ; 14: 131-4$.

Tsubokawa T, Katayama Y, Yamamoto T, Hirayama T, Koyama S. Chronic motor cortex stimulation in patients with thalamic pain. J Neurosurg. 1993;78:393-401.

Vaculín S, Franek M, Yamamotová A, Rokyta R. Motor cortex stimulation in rats with chronic constriction injury. Exp Brain Res. 2008;185:331-5.

Vanegas H, Schaible HG. Descending control of persistent pain: inhibitory or facilitatory? Brain Res Brain Res Rev. 2004;46(3):295-309.

Viisanen H, Pertovaara A. Antinociception by motor cortex stimulation in the neuropathic rat: does the locus coeruleus play a role? Exp Brain Res. 2010a;201:283-96. 
Viisanen H, Pertovaara A. Roles of the rostroventromedial medulla and the spinal 5HT(1A) receptor in descending antinociception induced by motor cortex stimulation in the neuropathic rat. Neurosci Lett. 2010b;476:133-7.

Zimmermann M. Ethical guidelines for investigations of experimental pain in conscious animals. Pain. 1983;16:109-10. 